\title{
Inhibition of methanogenesis by nitrate, with or without defaunation, in continuous culture
}

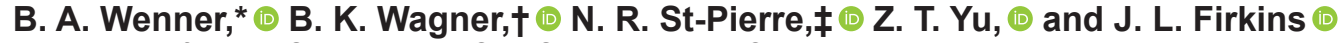 \\ Department of Animal Sciences, The Ohio State University, Columbus 43210
}

\begin{abstract}
Within the rumen, nitrate can serve as an alternative sink for aqueous hydrogen $\left[\mathrm{H}_{2}(\mathrm{aq})\right]$ accumulating during fermentation, producing nitrite, which ideally is further reduced to ammonium but can accumulate under conditions not yet explained. Defaunation has also been associated with decreased methanogenesis in meta-analyses because protozoa contribute significantly to $\mathrm{H}_{2}$ production. In the present study, we applied a $2 \times 2$ factorial treatment arrangement in a $4 \times 4$ Latin square design to dual-flow continuous culture fermentors $(\mathrm{n}=$ 4). Treatments were control without nitrate $\left(-\mathrm{NO}_{3}{ }^{-}\right)$ versus with nitrate $\left(+\mathrm{NO}_{3}{ }^{-} ; 1.5 \%\right.$ of diet dry matter $)$, factorialized with normal protozoa (faunated, FAUN) versus defaunation (DEF) by decreasing the temperature moderately and changing filters over the first $4 \mathrm{~d}$ of incubation. We detected no main effects of DEF or interaction of faunation status with $+\mathrm{NO}_{3}{ }^{-}$. The main effect of $+\mathrm{NO}_{3}{ }^{-}$increased $\mathrm{H}_{2}(\mathrm{aq})$ by $11.0 \mu M(+117 \%)$ compared with $-\mathrm{NO}_{3}{ }^{-}$. The main effect of $+\mathrm{NO}_{3}{ }^{-}$also decreased daily $\mathrm{CH}_{4}$ production by $8.17 \mathrm{mmol} \mathrm{CH}_{4} / \mathrm{d}$ (31\%) compared with $-\mathrm{NO}_{3}{ }^{-}$. Because there were no treatment effects on neutral detergent fiber digestibility, the main effect of $+\mathrm{NO}_{3}{ }^{-}$also decreased $\mathrm{CH}_{4}$ production by $1.43 \mathrm{mmol}$ of $\mathrm{CH}_{4} / \mathrm{g}$ of neutral detergent fiber degraded compared with $-\mathrm{NO}_{3}{ }^{-}$. There were no effects of treatment on other nutrient digestibilities, $\mathrm{N}$ flow, or microbial $\mathrm{N}$ flow per gram of nutrient digested. The spike in $\mathrm{H}_{2}(\mathrm{aq})$ after feeding $\mathrm{NO}_{3}{ }^{-}$provides evidence that methanogenesis is inhibited by substrate access rather than concentration, regardless of defaunation, or by direct inhibition of $\mathrm{NO}_{2}^{-}$. Methanogens were not decreased by defaunation, suggesting a compensatory increase in non-protozoa-associated methanogens or
\end{abstract}

Received February 6, 2020.

Accepted March 29, 2020.

*Corresponding author: wenner.20@osu.edu

†Current location: Department of Population Health and Pathobiology, College of Veterinary Medicine, North Carolina State University, Raleigh, NC 27606.

$\ddagger$ Current location: Perdue AgriBusiness, Salisbury, MD 21804. an insignificant contribution of protozoa-associated methanogens. Despite adaptive reduction of $\mathrm{NO}_{3}{ }^{-}$to $\mathrm{NH}_{4}{ }^{+}$and methane inhibition in continuous culture, practical considerations such as potential to depress dry matter intake and on-farm ration variability should be addressed before considering $\mathrm{NO}_{3}{ }^{-}$as an avenue for greater sustainability of greenhouse gas emissions in US dairy production.

Key words: nitrate, protozoa, continuous culture, aqueous hydrogen

\section{INTRODUCTION}

The impact of dairy cattle on enteric $\mathrm{CH}_{4}$ emissions is estimated to contribute approximate $3.9 \%$ of total anthropogenic $\mathrm{CH}_{4}$ in the United States (US EPA, 2013). The primary route of methanogenesis consumes aqueous $\mathrm{H}_{2}\left[\mathbf{H}_{2}(\mathbf{a q})\right]$ via reduction of $\mathrm{CO}_{2}$ or, alternatively, formate (Yang et al., 2016). Rumen protozoa produce both formate and $\mathrm{H}_{2}$, but ruminal formate metabolism is poorly understood compared with interspecies $\mathrm{H}_{2}$ transfer (Tapio et al., 2017). The production of $\mathrm{CH}_{4}$ pulls release of $\mathrm{H}_{2}$ into the rumen via hydrogenases in bacteria, protozoa, and fungi. This interspecies $\mathrm{H}_{2}$ transfer to methanogens is integrally linked in ruminal VFA metabolism; these 2 processes are readily studied in continuous culture because net (after recycling) VFA production can be measured without absorption or endproduct feedback, and headspace $\mathrm{CH}_{4}$ and $\mathrm{H}_{2}(\mathrm{aq})$ can be directly measured rather than estimated (Wenner et al., 2017).

Some electron acceptors with a higher redox potential, such as $\mathrm{NO}_{3}{ }^{-}$or $\mathrm{SO}_{4}{ }^{2-}$ (van Zijderveld et al., 2010; Leng, 2014), outcompete $\mathrm{CO}_{2}$. Thus, rumen microbial reducers of these electron acceptors can divert $\mathrm{H}_{2}(\mathrm{aq})$ away from methanogenesis from $\mathrm{CO}_{2}$ (Ungerfeld and Kohn, 2006; Morgavi et al., 2010). Nitrate has potential to contribute $\mathrm{NH}_{3}-\mathrm{N}$ that is assimilated into microbial protein (Lee and Beauchemin, 2014; Wang et al., 2018); however, $\mathrm{NO}_{3}{ }^{-}$and especially its reduction product $\mathrm{NO}_{2}{ }^{-}$, can be toxic to some rumen bacteria and methanogens (Latham et al., 2016). When animals are adapted gradually, $\mathrm{NO}_{3}{ }^{-}$is a reliable $\mathrm{CH}_{4}$ mitigation 
strategy (van Zijderveld et al., 2010; 2011a,b), albeit sometimes at the expense of decreased DMI (Lee and Beauchemin, 2014; Meller et al., 2019).

Nitrate represents a predictable treatment to test the theories of Janssen (2010) regarding concentration of $\mathrm{H}_{2}(\mathrm{aq})$ and its role in shifting VFA production pathways away from acetate and $\mathrm{CH}_{4}$ production. The relationship between $\mathrm{H}_{2}(\mathrm{aq})$ and methanogenesis is clear (Janssen, 2010), but the feedback of increased $\mathrm{H}_{2}(\mathrm{aq})$ concentration on VFA pathways is less clear (van Lingen et al., 2016; Wenner et al., 2017), particularly because of transcriptional regulation by methanogens and alternative pathways by bacteria (Greening et al., 2019). Both $\mathrm{NO}_{3}{ }^{-}$reducers and methanogens compete for $\mathrm{H}_{2}$ (aq) (van Zijderveld et al., 2010; Leng, 2014; Zhao et al., 2015), so both processes increase total $\mathrm{H}_{2}$ production. However, $\mathrm{H}_{2}(\mathrm{aq})$ used in $\mathrm{NO}_{3}{ }^{-}$reduction should not be available to reduce fumarate and could decrease propionate production (Yang et al., 2016). Consequently, whether $\mathrm{NO}_{3}{ }^{-}$changes the acetate: propionate ratio probably depends on $\mathrm{H}_{2}(\mathrm{aq})$.

Protozoa possess hydrogenosomes or mitosomes that release $\mathrm{H}_{2}$ or formate (Hackstein and Tielens, 2010) that are the main substrates for ruminal methanogens and, as such, have a close relationship with some methanogens (Ushida, 2010; Belanche et al., 2014; Valle et al., 2015). The association of protozoa with bacteria and methanogens has led some researchers to suggest defaunation (complete removal of ruminal protozoa) as a method of improving efficiency of microbial protein synthesis (Eugène et al., 2004) and overall dietary N usage efficiency (Hristov and Jouany, 2005) while mitigating $\mathrm{CH}_{4}$ production in ruminant agriculture, although the latter results are not always consistent (Tapio et al., 2017; Ungerfeld, 2018). Protozoa help stabilize ruminal $\mathrm{pH}$, tend to increase butyrate concentration, and promote fiber degradation directly or indirectly by cellulolytic bacteria or fungi (Jouany and Ushida, 1999; Newbold et al., 2015) or by physically shredding fibrous feed particles (Dehority, 2010). Moreover, methanogens need not necessarily be close symbionts with protozoa but, instead, can be continuously recruited (Park and $\mathrm{Yu}, 2018$ ). Thus, further research is needed to investigate potential interactions of protozoa with other $\mathrm{CH}_{4}$ mitigation strategies such as feeding $\mathrm{NO}_{3}{ }^{-}$.

We hypothesized that dietary $\mathrm{NO}_{3}{ }^{-}$treatment would provide an alternate sink for $\mathrm{H}_{2}(\mathrm{aq})$ to inhibit methanogens and shift their relative abundance toward those associating with protozoa. The combination of treatments was proposed to interact to suppress methanogenesis by removing protozoa as a supportive mechanism for associated methanogens. We also hypothesized that $\mathrm{NO}_{3}{ }^{-}$would shift fermentation toward acetate, especially after defaunation (a positive interaction), unless $\mathrm{H}_{2}(\mathrm{aq})$ increased enough to shift stoichiometry toward propionate. Our objective was to use continuous culture fermentors as a model to measure concentration of $\mathrm{H}_{2}(\mathrm{aq}), \mathrm{CH}_{4}$ production, VFA production, and fiber digestibility to test these hypotheses and compare microbial communities to help explain results.

\section{MATERIALS AND METHODS}

\section{Experimental Design}

The present study was conducted as a $2 \times 2$ factorial arrangement of treatments in a $4 \times 4$ Latin square experimental design using dual-flow continuous culture fermentors $(\mathrm{n}=4)$. Once daily, all fermentors were fed $40 \mathrm{~g}$ (DM) of a pelleted 50:50 forage:concentrate diet $(37.5 \% \mathrm{NDF}, 19.5 \% \mathrm{NSC}, 15.4 \% \mathrm{CP})$. The pelleted concentrate consisted of shelled corn (36.9\%), soybean hulls (40.4\%), dried distillers grains (10.0\%), soybean meal $(9.1 \%)$, corn oil $(1.8 \%)$, and a vitamin/ mineral mix $(1.8 \%)$ containing $36.6 \% \mathrm{Na}, 56.4 \% \mathrm{Cl}$, $3,500 \mathrm{mg} / \mathrm{kg} \mathrm{Zn}, 2,800 \mathrm{mg} / \mathrm{kg} \mathrm{Mn}, 1,750 \mathrm{mg} / \mathrm{kg} \mathrm{Fe}$, $350 \mathrm{mg} / \mathrm{kg} \mathrm{Cu}, 70 \mathrm{mg} / \mathrm{kg} \mathrm{I}$, and $70 \mathrm{mg} / \mathrm{kg}$ Co. All treatments were fed the base diet. Isonitrogenous treatments were control without $\left(-\mathrm{NO}_{3}{ }^{-}\right.$; supplemental urea at $0.7 \%$ and $\mathrm{NaCl}$ at $1.4 \%$ of diet $\mathrm{DM}$, respectively) versus with $\left(+\mathrm{NO}_{3}{ }^{-} ; 1.5 \%\right.$ of diet $\mathrm{DM}$ provided as $\mathrm{NO}_{3}^{-}$in a sodium salt) nitrate, factorialized with faunated (FAUN) versus defaunated (DEF) fermentor contents. To prevent uneven adaptation exposure to $\mathrm{NO}_{3}{ }^{-}$between DEF and FAUN, $+\mathrm{NO}_{3}{ }^{-}$was not dosed until defaunation was completed.

\section{Continuous Culture Operation}

Dual-flow continuous culture fermentors $(\mathrm{n}=4$; Hoover et al., 1976) were given $8 \mathrm{~d}$ of adaptation with sampling periods lasting $3 \mathrm{~d}$, for a total of $11 \mathrm{~d}$ per experimental period. Each experimental period was initiated by sampling the rumen contents of 2 ruminally cannulated lactating Jersey cows. These cows were fed a standard lactating diet similar to that used in a previous continuous culture study (Welty et al., 2019) consisting of $52 \%$ corn silage, $18 \%$ alfalfa hay, and $30 \%$ corn/soybean meal premix; no cows used in this study had been previously fed $\mathrm{NO}_{3}{ }^{-}$. Rumen contents were squeezed through 2 layers of cheesecloth into warmed, insulated containers and transported to the laboratory at $39^{\circ} \mathrm{C}$ within $30 \mathrm{~min}$. Inocula sources were pooled from 2 cows per period and added to fermentors at $50 \%$ of total working volume. Clarified rumen fluid (centrifuged at $15,000 \times g, 4^{\circ} \mathrm{C}, 15 \mathrm{~min}$, and then autoclaved) was diluted 1:20 with anaerobic buffer for the first 2 d of each period to better adapt microbial contents to fermentors. 
Average fermentor volume was $1.71 \mathrm{~L}( \pm 0.09 \mathrm{~L})$, stirring was set to $50 \mathrm{rpm}$, temperature was set at $39^{\circ} \mathrm{C}$, total buffer dilution rate was fixed at $7.0 \% / \mathrm{h}$ for all treatments, and solids dilution rate was fixed at 5.0\%/h for all treatments. Buffer $\mathrm{pH}$ was maintained at 6.75 under continuous bubbling of $\mathrm{CO}_{2}$ to maintain anaerobic conditions; constant buffer $\mathrm{pH}$ allowed a diurnal post-feeding shift in $\mathrm{pH}$ to better reflect normal rumen function (Wenner et al., 2017). Fermentor pH ranged from 6.8 pre-feeding to 6.2 at its nadir, approximately $8 \mathrm{~h}$ post-feeding, before returning to 6.8 gradually for the last $16 \mathrm{~h}$ of the daily cycle. Fermentor buffer was made according to Weller and Pilgrim (1974); $10 \mathrm{mg} /$ dL urea was added to buffer to maintain approximately 5 to $10 \mathrm{mg} / \mathrm{dL} \mathrm{NH}_{3}-\mathrm{N}$ at $4 \mathrm{~h}$ post-feeding after $5 \mathrm{~d}$ of adaptation.

Fermentor $\mathrm{CH}_{4}$ and $\mathrm{H}_{2}$ emissions were measured using the Micro-Oxymax detection system (Columbus Instruments Inc., Columbus, $\mathrm{OH}$ ) as previously described (Wenner et al., 2017; Wagner et al., 2018). Gas production data were taken in tandem with fermentor effluent samples on the last $3 \mathrm{~d}$ of each experimental period. Ammonium sulfate enriched with $10 \%{ }^{15} \mathrm{~N}$ was dosed in a priming dose of $50 \mathrm{mg}$ on $\mathrm{d} 5$ and added to the buffer at $25 \mathrm{mg} / \mathrm{L}$ from d 5 to 10 for a desired enrichment of $0.2 \%$ atom excess.

\section{Defaunation of Fermentors}

Fermentors with FAUN treatments were equipped with filters designed to retain protozoa with impeller speeds of about $50 \mathrm{rpm}$ and a prefilter wrapped around a 50- $\mu \mathrm{m}$ mesh filter (Karnati et al., 2009a). Increased stirring to prevent settling of isotrichids combined with $300-\mu \mathrm{m}$ wire mesh filters to wash out particle-associating entodiniomorphids defaunated fermentors in one previous study (Karnati et al., 2009a) but not another (Fowler et al., 2015), nor in our preliminary studies. Hence, for DEF treatments, fermentors were fitted with 300- $\mu \mathrm{m}$ wire mesh filters (Karnati et al., 2009a), mixed at $100 \mathrm{rpm}$, and had temperature decreased to $34^{\circ} \mathrm{C}$. Decreased temperature increased protozoal generation time and eliminated protozoa in batch cultures after 5 transfers (Dehority, 2010). Given our turnover rate of $1.68 / \mathrm{d}$, we expected 3 to $4 \mathrm{~d}$ would be sufficient to fully defaunate fermentors ( 5.0 to 6.7 turnovers). At the end of the d 4, DEF fermentors were returned to $50 \mathrm{rpm}$ and $39^{\circ} \mathrm{C}$ (same as FAUN).

\section{Sample Collection and Analysis}

From d 9 to 11, daily fermentor effluent was collected cumulatively for $24 \mathrm{~h}$ post-feeding in containers on ice. A $30 \%$ subsample by weight of the mixed total effluent was aspirated with a 6.35 -mm-diameter tube to prevent sampling bias against larger particles and pooled by fermentor within period. Sampled fermentor effluent was dried at $55^{\circ} \mathrm{C}$ and stored for various analyses at $-20^{\circ} \mathrm{C}$. A subsample of dried effluent was used to determine $\mathrm{DM}$ at $105^{\circ} \mathrm{C}$ and subsequently ashed at $550^{\circ} \mathrm{C}$ (AOAC, 1990). Effluent $\mathrm{N}$ was determined by the Kjeldahl method (AOAC, 1990), and $\mathrm{NH}_{3}-\mathrm{N}$ remaining in oven-dried samples was determined by dissolving approximately $0.2 \mathrm{~g}$ of sample in $1 \mathrm{~mL}$ of distilled $\mathrm{H}_{2} \mathrm{O}$ followed by colorimetric analysis (Chaney and Marbach, 1962) to determine NAN flow by subtraction. Kjeldahl analysis only recovers a portion of escaped $\mathrm{NO}_{3}{ }^{-}$or $\mathrm{NO}_{2}{ }^{-}$, which Meller et al. (2019) estimated to be $29.4 \%$. However, NAN should be removing $\mathrm{NO}_{3}{ }^{-}$or $\mathrm{NO}_{2}{ }^{-}$along with $\mathrm{NH}_{4}{ }^{+}$(Welty et al., 2019). Neutral detergent fiber was determined with use of heat-stable amylase and sodium sulfite (Van Soest et al., 1991). Starch and water-soluble carbohydrates were commercially analyzed by Dairy One Forage Lab (Ithaca, NY) and summed as NSC. A 50-mL aliquot of daily effluent was acidified with $3 \mathrm{~mL}$ of $6 \mathrm{~N} \mathrm{HCl}$ and composited by fermentor within period and stored at $-20^{\circ} \mathrm{C}$. Samples were later thawed, centrifuged $\left(15,000 \times g, 4^{\circ} \mathrm{C}, 15\right.$ min), and filtered through Whatman No. 1 filter paper (Whatman International, Maidstone, UK) for analysis of $\mathrm{NH}_{3}-\mathrm{N}$ (Chaney and Marbach, 1962) and VFA by gas-liquid chromatography (Harvatine et al., 2002). Analysis of ${ }^{15} \mathrm{~N}$ enrichment was performed by ion-ratio mass spectrometry after combustion and ionization (Delta V Advantage Isotope-Ratio Mass Spectrometer; ThermoFinnigan MAT GmbH, Bremen, Germany) by C. Lee (The Ohio State University, Ohio Agricultural Research and Development Center, Wooster).

Using the protozoal N:cell ratio previously reported by Sylvester (2005), we estimated protozoal N based on daily outflow of protozoal cells in effluent. Sylvester's (2005) samples were primarily small entodiniomorphids and were approximated at $0.5 \mathrm{ng} /$ cell, but N:cell can range to more than 40 times that value (Weller and Pilgrim, 1974; Karnati et al., 2009a; Ye et al., 2018). Given that larger cells should contain more N but N concentration could not be directly determined in the present study, large entodiniomorphids and all Isotrichidae were assigned a conservative value of $1 \mathrm{ng}$ of N/cell, whereas Charonina and small entodiniomorphids were assigned $0.5 \mathrm{ng}$ of $\mathrm{N} /$ cell. This approximated protozoal $\mathrm{N}$ was subtracted from daily NAN flow before using ${ }^{15} \mathrm{~N}$ enrichment of bacterial to estimate bacterial $\mathrm{N}$ flow.

\section{Microbial Sample Processing}

On d 7 of each experimental period, fermentors were mixed at $150 \mathrm{rpm}$ for $15 \mathrm{~s}$ to sample mixed fermentor 
contents by transfer pipette with a 6.25 -mm-diameter orifice. Samples were taken at $0,1.5,3,6$, and $12 \mathrm{~h}$ post-feeding. One $10-\mathrm{mL}$ aliquot was sampled and stored at $-80^{\circ} \mathrm{C}$ for DNA extraction. An additional 8-mL aliquot of effluent and 10-mL aliquot of agitated fermentor contents were taken and fixed in $2 \mathrm{~mL}$ and 5 $\mathrm{mL}$, respectively, of $50 \%$ formalin for protozoal counts according to Dehority (1993). Because of the unexpected enrichment of Charonina ventriculi (confirmed by B. Dehority, The Ohio State University, Columbus; personal communication), protozoal counts were differentiated morphologically into the following categories: Charonina, small entodiniomorphids $(<100 \mu \mathrm{m}$ in length), large entodiniomorphids ( $>100 \mu \mathrm{m}$ in length), and family Isotrichidae.

Microbial DNA was extracted from fermentor samples pooled by fermentor within period and extracted in a manner similar to that of Faulkner et al. (2017). Briefly, frozen samples of fermentor contents were thawed overnight at $4^{\circ} \mathrm{C}$, mixed by inversion, pooled, and a 1-mL subsample centrifuged $(16,000 \times$ $\left.g, 4^{\circ} \mathrm{C}, 10 \mathrm{~min}\right)$. Supernatant was discarded and DNA extraction proceeded with the repeated bead beating and column purification approach of $\mathrm{Yu}$ and Morrison (2004). Quantification of DNA was performed using a NanoDrop 1000 Spectrophotometer (NanoDrop, Wilmington, DE) for sequencing and using the Quant-iT ds DNA assay (Thermo Fisher Scientific Inc., Waltham, MA) for quantitative real-time PCR (qPCR).

A pooled reference of all samples was used for qPCR analyses of total bacteria and total archaea by targeting the 16S rRNA gene using an Mx3000 real-time polymerase chain reaction system (Stratagene California, La Jolla, CA). Domain-specific primers used in qPCR are listed in Supplemental Table S1 (https://doi.org/10 $.3168 /$ jds.2020-18325) and qPCR conditions matched that of Stiverson et al. (2011).

The diversity and composition of the prokaryotes in the fermentor samples were analyzed using metataxonomics similar to that described by Faulkner et al. (2017). Briefly, amplicon libraries were prepared by amplifying the V4-V5 hypervariable region of the $16 \mathrm{~S}$ rRNA gene using a universal primer, with each library having a unique barcode for multiplexing. The amplicon libraries were pooled and sequenced $(2 \times 300 \mathrm{bp}$ paired-end sequencing) on a MiSeq platform (Illumina Inc., San Diego, CA). The sequences were processed and then analyzed using QIIME version 1.5 (Caporaso et al., 2010). Only sequences $(\sim 247,000)$ with a Phred score $\geq 20$ and free from chimera were analyzed. Operational taxonomic units (OTU) were clustered at $97 \%$ similarity with Uclust (Edgar, 2013; Quast et al., 2013) and the Silva database (v123, http://www.arb-silva .de/), which was also used to taxonomically classify the OTU. Only major phyla, family, and genera with a relative sequence abundance $\geq 0.5 \%$ were included in statistical analysis.

\section{Hourly Filtrate Sampling}

Using a y-valve septum on the filtrate line (Wenner et al., 2017), $10 \mathrm{~mL}$ each of filtrate was sampled from the fermentors at $0,0.5,1,1.5,2,2.5,3,4,6,8$, and $12 \mathrm{~h}$ post-feeding on $\mathrm{d} 9,10$, and 11 . Samples were acidified with $1 \mathrm{~mL}$ of $6 \mathrm{~N} \mathrm{HCl}$ and analyzed for $\mathrm{NH}_{3}-\mathrm{N}$ (Chaney and Marbach, 1962), VFA (Harvatine et al., 2002), and both $\mathrm{NO}_{3}{ }^{-}$and $\mathrm{NO}_{2}^{-}$(O'Dell, 1993). At each of the same time points, $20 \mathrm{~mL}$ of filtrate was sampled from the septum and injected into 60-mL glass culture bottles (Wheaton Glass, Millville, NJ) that were prefilled with $5 \mathrm{~mL}$ of $5 \mathrm{M} \mathrm{H}_{3} \mathrm{PO}_{4}$, flushed with $\mathrm{N}_{2}$, and sealed with a butyl rubber stopper for $\mathrm{H}_{2}$ (aq) measurement according to Wenner et al. (2017). Partial pressure of $\mathrm{H}_{2}$ in the headspace of the fermentors was also used to predict $\mathrm{H}_{2}(\mathrm{aq})$ using Henry's Law for comparison of predicted versus measured $\mathrm{H}_{2}(\mathrm{aq})$. Hydrogen recovery was estimated using VFA production, including valerate but not caproate (Guyader et al., 2017) and including the $\mathrm{H}_{2}(\mathrm{aq})$ incorporation from $\mathrm{NO}_{3}{ }^{-}$reduction.

\section{Statistical Analysis}

Daily effluent nutrient measurements and ${ }^{15} \mathrm{~N}$ enrichment data were analyzed using the MIXED procedure of SAS 9.4 (SAS Institute Inc., Cary, NC) according to the following model:

$$
Y_{i j k l m}=\mu+N_{i}+D_{j}+(N \times D)_{i j}+p_{k}+f_{l}+\varepsilon_{i j k l m},
$$

where $Y_{i j k l m}$ is the dependent variable, $\mu$ is the overall population mean, $N_{i}$ is the fixed effect of $i$ th $\mathrm{NO}_{3}{ }^{-}$ treatment $\left(i=-\mathrm{NO}_{3}{ }^{-},+\mathrm{NO}_{3}{ }^{-}\right), D_{j}$ is the fixed effect of $j$ th faunation treatment ( $j=$ faunated, defaunated $),(N$ $\times D)_{i j}$ is the interaction of $\mathrm{NO}_{3}{ }^{-}$and defaunation, $p_{k}$ is the random effect of $k$ th period $(k=1,2,3,4), f_{l}$ is the random effect of $l$ th fermentor $(l=1,2,3,4)$, and $\varepsilon_{i j k l m}$ is the residual error, assumed independent and $\sim N\left(0, \sigma_{e}^{2}\right)$.

For evaluations of protozoa, the effect of DEF (and its interaction with N) was removed. A Kenward-Roger degrees of freedom correction was applied to all dependent variables. For daily $\mathrm{CH}_{4}$ production, the random effect of $m$ th day $(m=1,2,3)$ was added to the model due to large daily variation in $\mathrm{CH}_{4}$ production between days. All hourly data were analyzed using repeated measures and the covariance structure with the lowest 
Bayesian information criterion. Gas production data over time post-feeding were fitted to an autoregressive heterogeneous (first-order) covariance structure using the PARM statement in SAS to specify starting variance parameters obtained using the MIVQUE0 statement; all other dependent variables were fitted to a first-order autoregressive covariance structure. Contrast statements tested the main effect of $\mathrm{NO}_{3}{ }^{-}$, faunation, or the $\mathrm{NO}_{3}{ }^{-} \times$faunation interaction when there were no repeated measures or for main effect treatment means when there was no interaction $(P>0.10)$; when treatment interacted with time, contrasts were performed at each time point simultaneously.

The overall prokaryotic microbiota among the treatments were compared using nonmetric multidimensional scaling (NMDS) based on Bray-Curtis dissimilarity using ANOSIM in R project (https://www.R-project .org/). Relative abundance of individual taxa based on sequencing data and quantification based on qPCR were analyzed using the same statistical model as above but through the $\mathrm{R}$ project (package vegan, http: //cran.r-project.org/web/packages/vegan/). All qPCR data were $\log _{10}$-transformed before analysis, but relative abundance data were left untransformed because of limitations in several popular transformation techniques described previously by Faulkner et al. (2017).

\section{RESULTS AND DISCUSSION}

\section{Protozoal Counts and Generation Time}

Our experiment required an initial drop of temperature to fully defaunate the continuous cultures. The increased stirring and filter porosity might have been less effective in fresh culture compared with fermentor contents $14 \mathrm{~d}$ into the experiment (Karnati et al., 2009a) due to the abundance of protozoa in fresh inocula (average $=7.56 \times 10^{5}$ cells $/ \mathrm{mL}$ ) that were given the opportunity to adapt to DEF treatment conditions. Reducing the temperature to $34^{\circ} \mathrm{C}$ (Dehority, 2010) was effective in eliminating protozoa from fermentors and should have minimal long-lasting effects on prokaryotes (B. Dehority, The Ohio State University; personal communication). However, we would caution that there was no way to verify that our defaunation protocol could not bias bacterial populations compared with control populations; there was no baseline bacterial population for comparison because DEF was imposed from inoculation. Following inoculation, protozoal abundance declined in both FAUN and DEF fermentors but stabilized at $1.35 \times 10^{4}$ cells $/ \mathrm{mL}$ for FAUN, whereas protozoa were microscopically undetectable for DEF after $4 \mathrm{~d}$. Methanogenesis, a key indicator of continuous culture viability, returned to pre-defaunation ranges $<2 \mathrm{~d}$ after returning temperature to $39^{\circ} \mathrm{C}$ (data not shown).

We observed no effects $(P>0.10)$ of $+\mathrm{NO}_{3}{ }^{-}$on protozoa counts, effluent flow of protozoa, or generation time (Table 1). The large, fibrolytic entodiniomorphids were almost washed out, leaving small Entodinium spp. as the primary group, which is typical in our conditions (Karnati et al., 2009a; Ye et al., 2018). Although $\mathrm{NO}_{2}{ }^{-}$interfered with protozoal motility (particularly that of isotrichids) and chemotaxis (Roman-Garcia et al., 2019), addition of $\mathrm{NO}_{3}{ }^{-}$to continuous cultures at the same dose as used in the present study (Welty et al., 2019) tended to increase Entodinium spp., which was attributed to nitrate reduction. Protozoal concentrations were not affected by feeding $\mathrm{NO}_{3}{ }^{-}$in sheep (van Zijderveld et al., 2010) but increased in dairy cows (Meller et al., 2019). Responses of protozoa to $\mathrm{NO}_{3}{ }^{-}$addition are poorly understood but might depend on better characterization of nitrate reductase activity (Yang et al., 2016; Roman-Garcia et al., 2019).

\section{Nutrient Digestibility and Nitrogen Flow}

Despite extensive bag washing, minute particles inherent in fermentors were not separable from protozoal cells per the method of Sylvester et al. (2005). Although feed $\mathrm{N}$ would dilute the ${ }^{15} \mathrm{~N}$ label, the high enrichment in washed samples from both FAUN and DEF treatments was presumably a result of extensive bacterial adherence to contaminating particulates because there were no protozoa present in DEF. We attempted to subtract FAUN from DEF washed samples to estimate protozoal $\mathrm{N}$ flow, but bacterial contamination of particles was either too severe or protozoal $\mathrm{N}$ contribution was relatively too small to be reliably detected in this manner. This prompted the use of estimated N composition of protozoal cells as referenced in the methods previously.

There were neither interactions nor main effects $(P$ $>0.10$ ) of treatment on apparent digestibilities of $\mathrm{OM}$ or NSC; NDF digestibility; $\mathrm{NH}_{3}-\mathrm{N}$ concentration; or effluent outflows of total N, microbial N, NAN, or nonammonia, non-microbial N (Table 2). The lack of effects for $+\mathrm{NO}_{3}{ }^{-}$was consistent with results using a similar $\mathrm{NO}_{3}{ }^{-}$dosage in continuous culture (Welty et al., 2019) at low urea inclusion. Similarly, nutrient digestibility was previously unaffected by the addition of $\mathrm{NO}_{3}{ }^{-}$in vivo (Nolan et al., 2010; van Zijderveld et al., 2011b). Estimated protozoal $\mathrm{N}$ was a relatively small fraction of total microbial $\mathrm{N}$ flow under our conditions, possibly contributing to the lack of effects for DEF treatment on NDF digestibility in the present study compared with in vivo conditions. The effect of defaunation on 
Table 1. Counts of protozoa populations within fermentors, calculated effluent flow, and generation time for continuous culture fermentors ${ }^{1}$

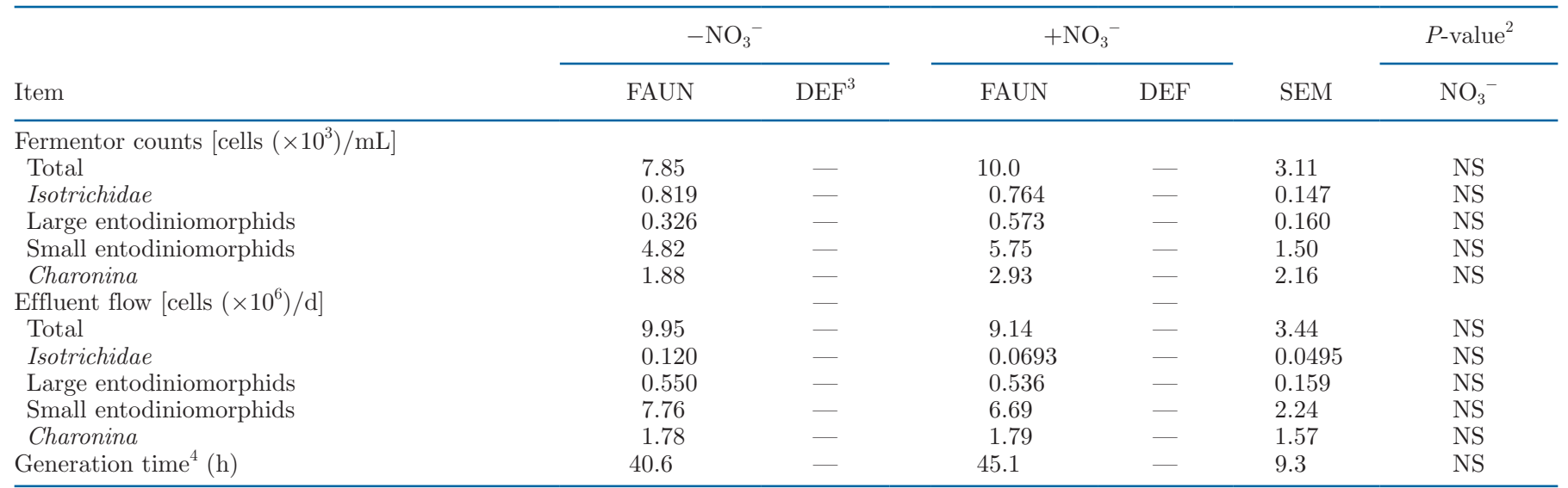

${ }^{1}$ Treatments: $-\mathrm{NO}_{3}{ }^{-}=$no nitrate, $+\mathrm{NO}_{3}{ }^{-}=$nitrate added at $1.5 \%$ of diet DM, FAUN $=$ no defaunation, DEF $=$ defaunated.

${ }^{2} P$-values reported for the main effects of $+\mathrm{NO}_{3}{ }^{-}, \mathrm{DEF}$, and their interaction. $\mathrm{NS}=P>0.15$.

${ }^{3} \mathrm{DEF}$ were confirmed to lack protozoa; as such, their numbers were zero and excluded from analysis.

${ }^{4}$ Generation time $=$ total pool size of cells (i.e., fermentor counts $\times$ fermentor volume) $/$ effluent flow of cells $/ \mathrm{d} \times 24 \mathrm{~h}$.

methanogenesis is variable (Morgavi et al., 2012) and typically accompanied by depressed NDF digestibility (Guyader et al., 2014; Newbold et al., 2015). Depressed NDF digestibility should decrease production of VFA and, consequently, also $\mathrm{H}_{2}$ and formate (Newbold et al., 2015). The association of methanogens with differing protozoal taxa is inconsistent (Tapio et al., 2017). Thus, further research is needed to sort out these interactions.

Table 2. Nutrient digestibilities and $\mathrm{N}$ flows to effluent in continuous culture fermentors ${ }^{1}$

\begin{tabular}{|c|c|c|c|c|c|c|c|c|}
\hline Item & \multicolumn{2}{|c|}{$-\mathrm{NO}_{3}^{-}$} & \multicolumn{2}{|c|}{$+\mathrm{NO}_{3}^{-}$} & SEM & \multicolumn{3}{|c|}{$P$-value ${ }^{2}$} \\
\hline Apparent OM digestibility (\%) & 43.7 & 43.1 & 39.5 & 42.9 & 2.4 & NS & NS & NS \\
\hline NDF digestibility $(\%)$ & 54.1 & 52.3 & 54.9 & 56.3 & 3.3 & NS & NS & NS \\
\hline $\mathrm{NH}_{3}-\mathrm{N}(\mathrm{mg} / \mathrm{dL})$ & 6.40 & 6.17 & 6.05 & 5.51 & 0.51 & NS & NS & NS \\
\hline \multicolumn{9}{|l|}{ Effluent $\mathrm{N}$ flows ${ }^{3}$} \\
\hline Bacterial N (g/d) & 0.534 & 0.543 & 0.520 & 0.554 & 0.037 & NS & NS & NS \\
\hline $\begin{array}{l}\text { Bacterial } \mathrm{N} \text { (g/kg of } \mathrm{OM} \\
\text { apparently degraded) }\end{array}$ & 33.2 & 34.3 & 35.8 & 35.1 & 3.0 & NS & NS & NS \\
\hline $\begin{array}{l}\text { Bacterial N (g/kg of NSC } \\
\text { apparently degraded) }\end{array}$ & 61.6 & 63.4 & 61.7 & 65.5 & 4.5 & NS & NS & NS \\
\hline $\begin{array}{c}\text { Bacterial N (g/kg of NDF } \\
\text { degraded) }\end{array}$ & 73.6 & 78.1 & 69.5 & 72.6 & 7.4 & NS & NS & NS \\
\hline NANMN (\% of N intake) & 34.7 & 32.9 & 36.1 & 34.3 & 3.8 & NS & NS & NS \\
\hline
\end{tabular}

${ }^{1}$ Treatments: $-\mathrm{NO}_{3}{ }^{-}=$no nitrate, $+\mathrm{NO}_{3}{ }^{-}=$nitrate added at $1.5 \%$ of diet DM, FAUN $=$ no defaunation, DEF $=$ defaunated. Effects of DEF are precluded, by design, from protozoal $\mathrm{N}$ flow.

${ }^{2} P$-values reported for the main effects of $-\mathrm{NO}_{3}{ }^{-}, \mathrm{DEF}$, and their interaction. $\mathrm{NS}=P>0.15$.

${ }^{3}$ Total $\mathrm{N}$ does not contain $\mathrm{N}$ from $\mathrm{NO}_{3}{ }^{-}$or $\mathrm{NO}_{2}{ }^{-}$that was not recovered by Kjeldahl analysis, but these should be subtracted in derivation of NAN anyway (Welty et al., 2019).

${ }^{4}$ Microbial $\mathrm{N}$ includes protozoal $\mathrm{N}$ for FAUN but bacterial $\mathrm{N}$ only for DEF.

${ }^{5}$ Percent of dietary $\mathrm{N}$ intake does not include $\mathrm{N}$ from buffer.

${ }^{6}$ Non-ammonia, non-microbial N. 


\section{Hourly Ammonia, Nitrate, and Nitrate Flows}

Analysis of filtrate effluent indicated that the main effect of $+\mathrm{NO}_{3}{ }^{-}$decreased $(P<0.05)$ the concentration of $\mathrm{NH}_{3} \mathrm{~N}$ for the first $1.5 \mathrm{~h}$ post-feeding (Figure $1 \mathrm{~A})$, but this effect was negated thereafter. The main effect of $+\mathrm{NO}_{3}^{-}$also increased $\mathrm{NO}_{3}{ }^{-}(P<0.01)$ and $\mathrm{NO}_{2}^{-}(P \leq 0.07)$ concentration post-feeding $(0.25$ to 2 $\mathrm{h}$ and 0.25 to $4 \mathrm{~h}$ post-feeding for Figure $1 \mathrm{~B}$ and $\mathrm{C}$, respectively), documenting not only delivery of dose but also the reduction of $\mathrm{NO}_{3}{ }^{-}$to $\mathrm{NO}_{2}{ }^{-}$and then to $\mathrm{NH}_{3}$. Nitrate reduction in adapted rumen fluid or cultures is rapid (Lee and Beauchemin, 2014; Welty et al., 2019). Protozoa might mediate a rapid response in unadapted cultures (Lin et al., 2011) and perhaps benefit from electron-transport phosphorylation linked to nitrate reductase (Welty et al., 2019). The latter authors reported that ${ }^{15} \mathrm{~N}$-labeled $\mathrm{NO}_{3}{ }^{-}$was incorporated into microbial protein in continuous cultures, presumably via $\mathrm{NH}_{3}$ assimilation. A similar numerical decrease in ruminal $\mathrm{NH}_{3}-\mathrm{N}$ concentration was observed in sheep with the addition of $\mathrm{NO}_{3}{ }^{-}$to the diet (van Zijderveld et al., 2010).

\section{Daily Production of VFA and Methane}

There was neither an interaction $(P>0.10)$ of $\mathrm{NO}_{3}{ }^{-}$ $\times$ DEF for any VFA nor any main effect of treatment $(P>0.10)$ on total VFA concentration (Table 3$)$. However, numerical differences contributed to trends for increased daily VFA production for both the main effect of $+\mathrm{NO}_{3}{ }^{-}\left(9.6 \%\right.$ increase by adding $\mathrm{NO}_{3}{ }^{-} ; P=$ $0.07)$ and of faunation status $(8.9 \%$ increase by DEF vs. FAUN; $P=0.09$ ). The increase in VFA production in the DEF treatment contrasts with a recent metaanalysis in which defaunation typically decreased total VFA concentration (Newbold et al., 2015) as explained by reduced NDF digestibility, which did not occur in our study. In addition, the bacteria displacing the protozoa probably rely more on de novo synthesis of longchain fatty acids and diverting carbon away from VFA production (Karnati et al., 2009a). However, that study had supplementary fat and nearly twice the counts of protozoa; thus, the loss of protozoa ( $16.7 \%$ of total microbial N) likely represented a greater impact on VFA production than in the present study. Production of total VFA on a molar basis also ignores the chain length of VFA. The main effect of DEF increased $(P<$ $0.01)$ the molar proportion of propionate and valerate and decreased $(P \leq 0.05)$ molar proportion of isovalerate and acetate:propionate. Defaunation previously increased the molar proportion of propionate (Demeyer and Van Nevel, 1979); because protozoa consume lactate more quickly than bacteria (Newbold et al., 1986),
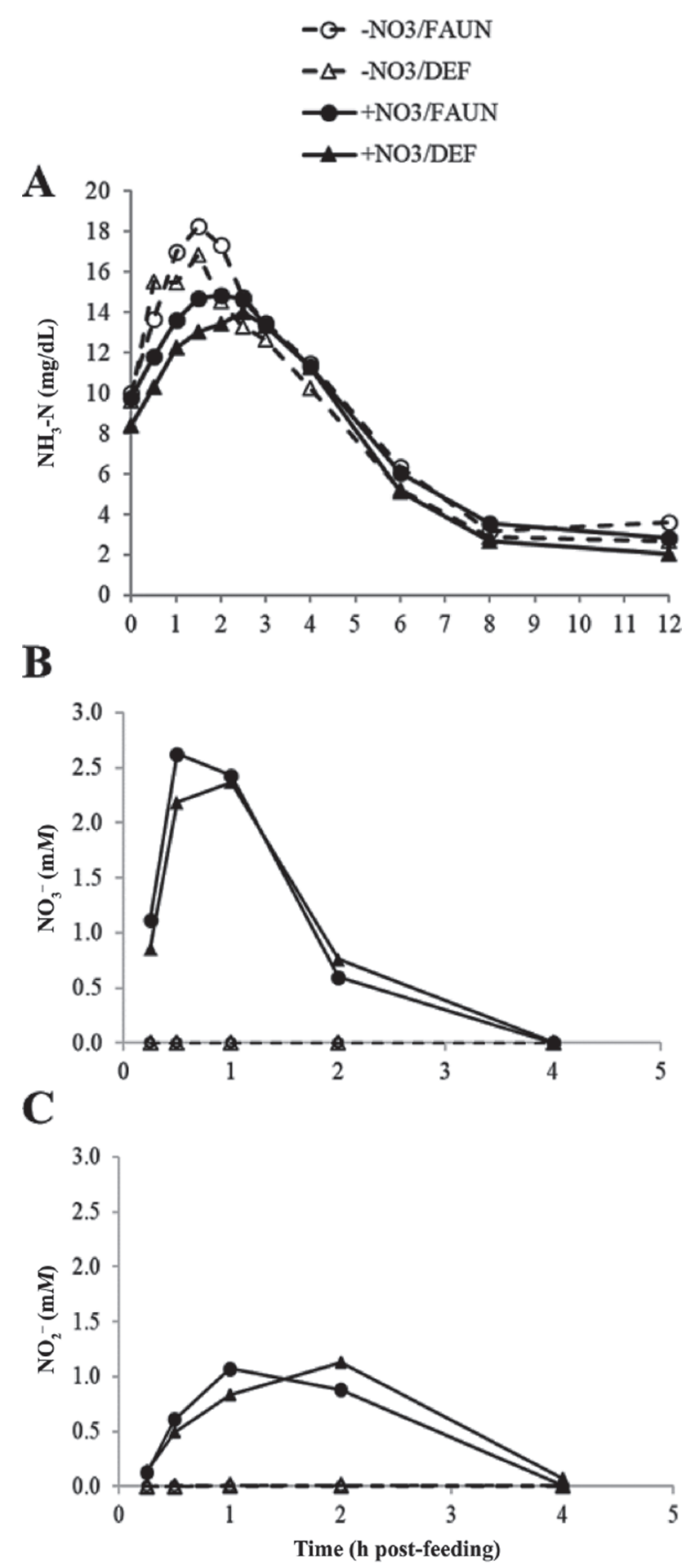

Figure 1. Concentrations of $\mathrm{NH}_{3}-\mathrm{N}(\mathrm{A}), \mathrm{NO}_{3}{ }^{-}$(B), and $\mathrm{NO}_{2}{ }^{-}(\mathrm{C})$ over time post-feeding in continuous culture fermentors treated or not with $\mathrm{NO}_{3}{ }^{-}$and with or without defaunation. Treatments: $-\mathrm{NO}_{3}{ }^{-}=$ no nitrate added, $+\mathrm{NO}_{3}{ }^{-}=$nitrate added at $1.5 \%$ of diet DM, FAUN $=$ no defaunation, $\mathrm{DEF}=$ defaunated. There was no interaction of $+\mathrm{NO}_{3}{ }^{-} \times \operatorname{DEF}(P>0.10)$. The main effect of $+\mathrm{NO}_{3}{ }^{-}$decreased $(P$ $<0.05) \mathrm{NH}_{3}-\mathrm{N}$ from 0.5 to $1.5 \mathrm{~h}$ post-feeding. The addition of $\mathrm{NO}_{3}{ }^{-}$ increased $(P<0.01)$ concentration of $\mathrm{NO}_{3}{ }^{-}$from 0.25 to $2 \mathrm{~h}$ postfeeding, and increased $(P<0.01) \mathrm{NO}_{2}{ }^{-}$concentration in solution for $0.25 \mathrm{~h}$ through $2 \mathrm{~h}$ post-feeding. There were trends for the main effect of DEF that decreased $(P<0.10) \mathrm{NH}_{3}-\mathrm{N}$ at 2 and $12 \mathrm{~h}$ post-feeding. Further, DEF tended to increase $(P=0.09) \mathrm{NO}_{2}^{-}$concentration in solution at $4 \mathrm{~h}$ post-feeding only. Pooled SEM: $0.947 \mathrm{mg} / \mathrm{dL}$ for $\mathrm{NH}_{3}-\mathrm{N}$, and 0.154 and $0.059 \mu \mathrm{M}$ for $\mathrm{NO}_{3}^{-}$and $\mathrm{NO}_{2}^{-}$, respectively. 
lactate concentration has often increased after defaunation (Williams and Coleman, 1992). However, Newbold et al. (2015) noted a lack of significance for lactate concentration (although numerically increased by 11\%) and for propionate molar percentage by defaunation. In contrast, those authors noted that defaunation typically decreases butyrate concentration, which did not occur in our study. The main effect of $+\mathrm{NO}_{3}{ }^{-}$decreased $(P \leq 0.02)$ the molar proportion of isobutyrate and valerate. The decrease in branched-chain VFA by feeding $\mathrm{NO}_{3}{ }^{-}$has been previously reported (van Zijderveld et al., 2010; Guyader et al., 2015) but not explained. Although acetate was expected to increase because added $\mathrm{NO}_{3}{ }^{-}$provides an alternate electron acceptor to fumarate, a precursor in propionate formation (Yang et al., 2016), neither molar proportion of acetate nor acetate:propionate was affected by $\mathrm{NO}_{3}{ }^{-}$in the present study.

Daily $\mathrm{CH}_{4}$ production was decreased $(P<0.01)$ by $30.8 \%$ by $+\mathrm{NO}_{3}{ }^{-}$compared with $-\mathrm{NO}_{3}{ }^{-}$, with no effect $(P>0.10)$ of DEF or interaction (Table 3). Thus, $\mathrm{CH}_{4}$ produced per unit of NDF degraded was decreased by $35.6 \%(P=0.01)$ because there was no treatment effect on NDF digestibility. The decrease in $\mathrm{CH}_{4}$ production in the present study is similar to that in previous publications in sheep (Nolan et al., 2010; van Zijderveld et al., 2010, 2011a), dairy cattle (van Zijderveld et al., 2011b), and in vitro (Patra and Yu, 2013; Welty et al., 2019), with greater inhibition of methanogenesis in unadapted batch culture (Zhou et al., 2012).

\section{Production Rates of Methane and Hydrogen}

Methanogenesis was inhibited $(P<0.01)$ by $+\mathrm{NO}_{3}{ }^{-}$ from 2 to $9 \mathrm{~h}$ post-feeding, with no effect of DEF or interaction $(P>0.10$, Figure $2 \mathrm{~A})$. The temporal effect of $+\mathrm{NO}_{3}{ }^{-}$is similar to results in sheep (Alaboudi and Jones, 1985) and limit-fed dairy cows (van Zijderveld et al., 2011a). The temporal and declining efficacy of $+\mathrm{NO}_{3}{ }^{-}$in the present study is likely a 3 -fold response of dosed $\mathrm{NO}_{3}{ }^{-}$being reduced by microbes, its passage in effluent, and more rapid fermentation post-feeding generating greater metabolic hydrogen (termed $[\mathbf{2 H}]$, with brackets indicating various cofactors) that declined with remaining degradable carbohydrate.

The lack of effect of DEF compared with FAUN or interaction of DEF with $+\mathrm{NO}_{3}^{-}$for $\mathrm{CH}_{4}$ production is contrary to our hypothesis and some previous studies that DEF would decrease methanogenesis (Newbold et al., 2015). Smaller cells should have lower activity relative to larger cells (Whitelaw et al., 1984); our low concentration of protozoa, especially large ones, might have contributed to the lack of effect of defaunation in the present study. However, defaunation has previously failed to decrease methanogenesis in continuous culture with more protozoa (Karnati et al., 2009a) and in vivo (Machmüller et al., 2003; Hegarty et al., 2008; Morgavi et al., 2012). Tapio et al. (2017) also described inconsistent responses to protozoal community structure among multiple studies.

Another possible explanation for the lack of effect in DEF or its interaction with $\mathrm{NO}_{3}{ }^{-}$is the compensatory contribution of fungi or cellulolytic bacterial consortia within biofilms toward total $\mathrm{H}_{2}$ production. Biofilms harbor a micro-environment with complex $\mathrm{H}_{2}$ transfer capacity where fibrolytic microbes and their symbiotic constituents benefit from methanogens decreasing the concentration of $\mathrm{H}_{2}(\mathrm{aq})$ within the close proximity of their local environment (Hegarty and Gerdes, 1999; Leahy et al., 2010; Leng, 2014). Fungi were not

Table 3. Effluent flow, VFA concentrations and production, and methane production for continuous culture fermentors ${ }^{1}$

\begin{tabular}{|c|c|c|c|c|c|c|c|c|}
\hline \multirow[b]{2}{*}{ Item } & \multicolumn{2}{|c|}{$-\mathrm{NO}_{3}^{-}$} & \multicolumn{2}{|c|}{$+\mathrm{NO}_{3}^{-}$} & \multirow[b]{2}{*}{ SEM } & \multicolumn{3}{|c|}{$P$-value ${ }^{2}$} \\
\hline & FAUN & DEF & FAUN & $\mathrm{DEF}$ & & $+\mathrm{NO}_{3}^{-}$ & DEF & $+\mathrm{NO}_{3}{ }^{-} \times \mathrm{DEF}$ \\
\hline Effluent (L/d) & 2.88 & 2.88 & 2.87 & 2.91 & 0.09 & NS & NS & NS \\
\hline $\operatorname{VFA}(\mathrm{m} M)$ & 48.7 & 52.9 & 53.5 & 57.3 & 2.9 & 0.12 & NS & NS \\
\hline \multicolumn{9}{|l|}{ Individual VFA (mol/100 mol) } \\
\hline $\operatorname{Acetate}(\mathrm{A})$ & 64.4 & 63.7 & 64.8 & 64.7 & 0.7 & 0.14 & NS & NS \\
\hline Propionate $(\mathrm{P})$ & 21.2 & 22.5 & 21.1 & 22.3 & 1.3 & NS & $<0.01$ & NS \\
\hline Isobutyrate $^{3}$ & 0.623 & 0.588 & 0.524 & 0.496 & 0.037 & 0.02 & NS & NS \\
\hline Butyrate & 10.5 & 10.4 & 10.7 & 9.77 & 0.77 & NS & NS & NS \\
\hline Isovalerate & 1.75 & 1.01 & 1.47 & 1.02 & 0.13 & NS & $<0.01$ & NS \\
\hline Valerate & 1.60 & 1.83 & 1.45 & 1.71 & 0.10 & 0.01 & $<0.01$ & NS \\
\hline $\mathrm{A}: \mathrm{P}$ & 3.06 & 2.87 & 3.11 & 2.96 & 0.20 & NS & 0.02 & NS \\
\hline VFA (mmol/d) & 140 & 152 & 153 & 167 & 8 & 0.07 & 0.09 & NS \\
\hline Methane (mmol/d) & 30.3 & 30.4 & 21.2 & 20.8 & 3.6 & $<0.01$ & NS & NS \\
\hline Methane per NDF (mmol/kg degraded) & 4.14 & 4.36 & 2.78 & 2.69 & 0.57 & 0.01 & NS & NS \\
\hline
\end{tabular}

${ }^{1}$ Treatments: $-\mathrm{NO}_{3}{ }^{-}=$no nitrate, $+\mathrm{NO}_{3}{ }^{-}=$nitrate added at $1.5 \%$ of diet DM, FAUN $=$ no defaunation, DEF $=$ defaunated.

${ }^{2} P$-values reported for the main effects of $-\mathrm{NO}_{3}{ }^{-}, \mathrm{DEF}$, and their interaction. $\mathrm{NS}=P>0.15$.

${ }^{3}$ Under current column conditions, 2-methylbutyrate was not separated from isobutyrate. 
quantified in the present study, but they might have contributed more $\mathrm{H}_{2}(\mathrm{aq})$ in the absence of protozoa, given their hydrogenase activity similar to protozoa (Hackstein and Tielens, 2010) and antagonism with protozoa but symbiosis with methanogens (Edwards et al., 2017).

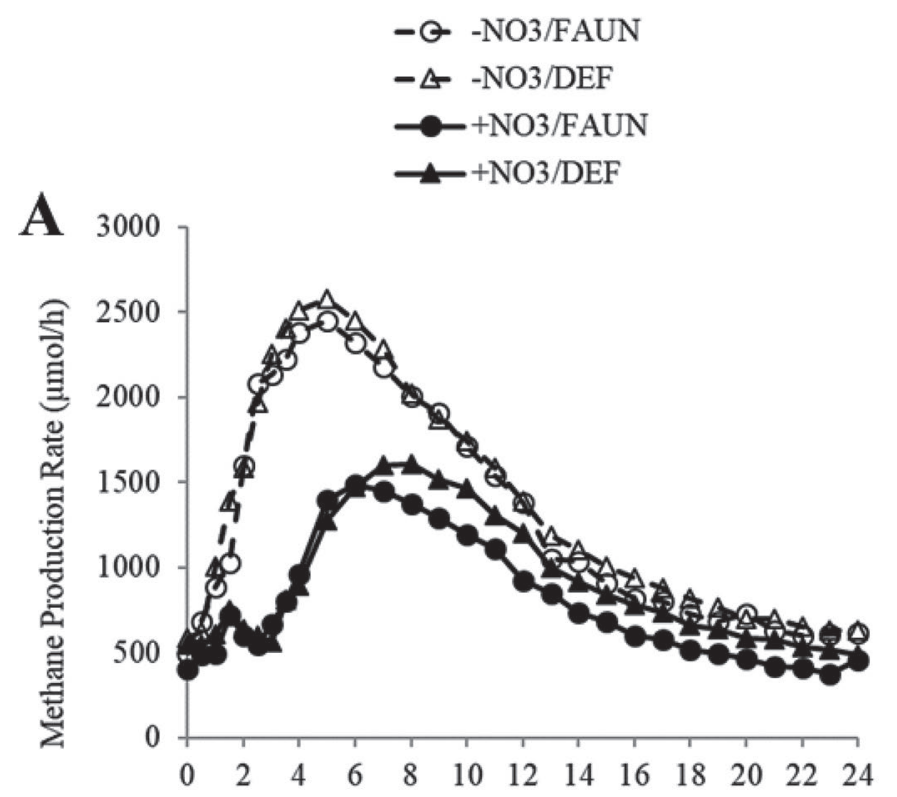

B

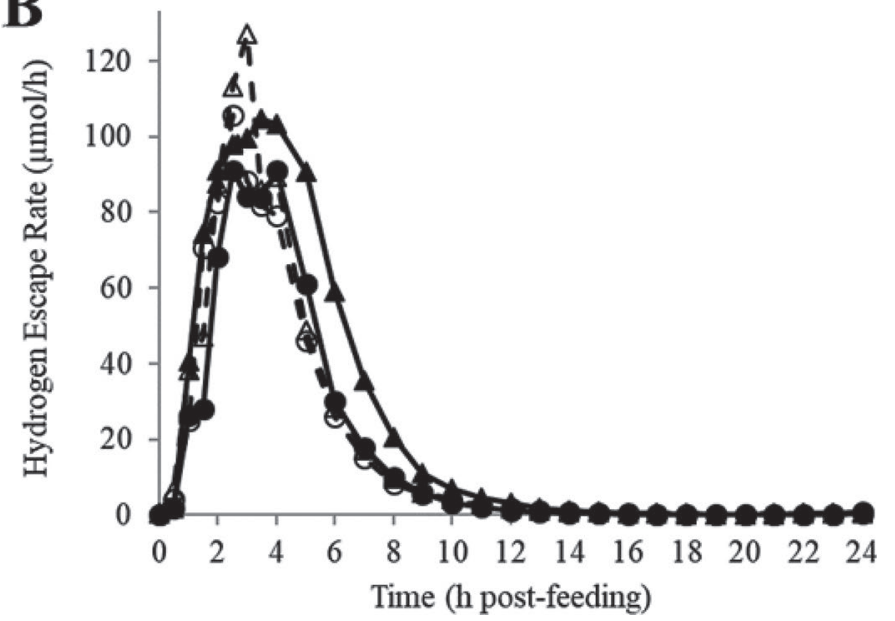

Figure 2. Rates of $\mathrm{CH}_{4}$ production (A) and emission of $\mathrm{H}_{2}$ (B) measured in headspace gas post-feeding for continuous culture fermentors treated or not with $\mathrm{NO}_{3}{ }^{-}$and with or without defaunation. Treatments: $-\mathrm{NO}_{3}{ }^{-}=$no nitrate added, $+\mathrm{NO}_{3}{ }^{-}=$nitrate added at $1.5 \%$ of diet DM, FAUN $=$ no defaunation, $\mathrm{DEF}=$ defaunated. For $\mathrm{H}_{2}$ escape, there was an interaction $(P=0.01)$ of $+\mathrm{NO}_{3}^{-} \times \mathrm{DEF}$ at $1.5 \mathrm{~h}$ post-feeding. Escape of $\mathrm{H}_{2}$ was increased $(P=0.04)$ by the main effect of $+\mathrm{NO}_{3}{ }^{-}$at $5 \mathrm{~h}$ post-feeding. Escape of $\mathrm{H}_{2}$ was increased $(P$ $=0.03$ ) by DEF at $3 \mathrm{~h}$ post-feeding. There was no effect of DEF or interaction of $+\mathrm{NO}_{3}{ }^{-} \times \mathrm{DEF}(P>0.10)$ on $\mathrm{CH}_{4}$ production rate. The main effect of $+\mathrm{NO}_{3}{ }^{-}$decreased $(P<0.05) \mathrm{CH}_{4}$ production rate from 2 to $9 \mathrm{~h}$ post-feeding. Pooled SEM: 13.1 and $210 \mu \mathrm{mol} / \mathrm{h}$ for $\mathrm{H}_{2}$ and $\mathrm{CH}_{4}$, respectively.

\section{$\mathrm{H}_{2}$ Escape and $\mathrm{H}_{2}(\mathrm{aq})$ Concentration}

The rate of $\mathrm{H}_{2}$ escape was increased by DEF at $3 \mathrm{~h}$ post-feeding $(P<0.05)$ and by $+\mathrm{NO}_{3}^{-}$at $5 \mathrm{~h}$ postfeeding $(P<0.05$, Figure $2 \mathrm{~B})$. Treatments interacted $(P<0.05)$ at $1.5 \mathrm{~h}$, with $\mathrm{H}_{2}$ rate being greater with the $-\mathrm{NO}_{3}^{-} / \mathrm{FAUN}$ and $+\mathrm{NO}_{3}^{-} / \mathrm{DEF}$ treatments than with $+\mathrm{NO}_{3}^{-} /$FAUN or $-\mathrm{NO}_{3}^{-} / \mathrm{DEF}$. Escape of $\mathrm{H}_{2}$ from culture is typically low but can result when $\mathrm{H}_{2}(\mathrm{aq})$ is incompletely captured by treatments that suppress methanogenesis (Ungerfeld, 2015a). Defaunation decreased $(P=0.02) \mathrm{H}_{2}(\mathrm{aq})$ concentration at $1 \mathrm{~h}$ post-feeding, but there was an interaction $(P=0.03)$ among treatments, with $\mathrm{H}_{2}(\mathrm{aq})$ of $+\mathrm{NO}_{3}^{-} /$FAUN being greatest, $+\mathrm{NO}_{3}{ }^{-} / \mathrm{DEF}$ intermediate, and $-\mathrm{NO}_{3}{ }^{-} /$ FAUN and $-\mathrm{NO}_{3}{ }^{-} / \mathrm{DEF}$ being not different from each other but less than both $\mathrm{NO}_{3}^{-}$treatments (Figure 3). Shortly after feeding ( 0.5 to $2.5 \mathrm{~h}$ ), the concentration of $\mathrm{H}_{2}(\mathrm{aq})$ was increased $(P<0.05)$ by the main effect of $+\mathrm{NO}_{3}{ }^{-}$. Concentrations of $\mathrm{H}_{2}(\mathrm{aq})$ were within a similar range of previously published measurements of $\mathrm{H}_{2}$ (aq) for rumen fluid (Wenner et al., 2017; Welty et al., 2019).

The lag in measured versus predicted $\mathrm{H}_{2}(\mathrm{aq})$ appears extended in FAUN versus DEF, especially with $+\mathrm{NO}_{3}{ }^{-}$ (Figure 4, panel B vs. A and especially panel D vs. C). Nitrate reductase inside protozoa might temporarily sequester $\mathrm{H}_{2}(\mathrm{aq})$, but this potential effect has not been tested. Instead, this lag likely supports temporary

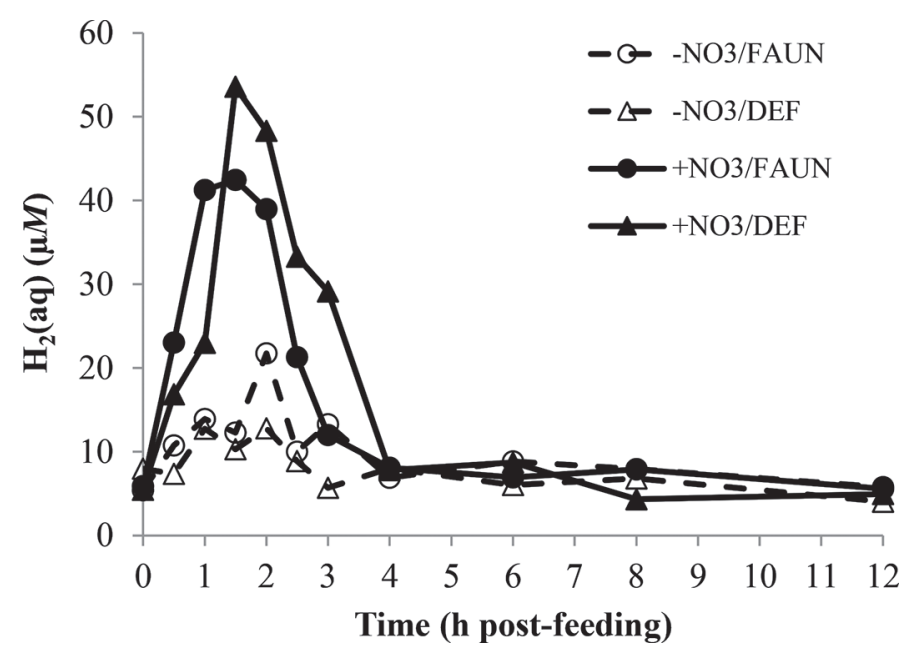

Figure 3. Concentration of aqueous hydrogen $\left[\mathrm{H}_{2}(\mathrm{aq})\right]$ over time post-feeding for continuous culture fermentors treated or not with $\mathrm{NO}_{3}{ }^{-}$and with or without defaunation. Treatments: $-\mathrm{NO}_{3}{ }^{-}=$no nitrate added, $+\mathrm{NO}_{3}{ }^{-}=$nitrate added at $1.5 \%$ of diet DM, FAUN $=$ no defaunation, $\mathrm{DEF}=$ defaunated. There was an interaction of $\mathrm{NO}_{3}{ }^{-} \times$ $\operatorname{DEF}(P=0.03)$ at $1 \mathrm{~h}$ post-feeding and a tendency $(P=0.07)$ for an interaction at $0 \mathrm{~h}$ post-feeding. The main effect of $+\mathrm{NO}_{3}{ }^{-}$increased $(P<0.05) \mathrm{H}_{2}(\mathrm{aq})$ from 0.5 to $2.5 \mathrm{~h}$ post-feeding, and the main effect of DEF decreased $(P=0.02) \mathrm{H}_{2}(\mathrm{aq})$ at $1 \mathrm{~h}$ post-feeding. Pooled SEM: $5.33 \mu M$. 

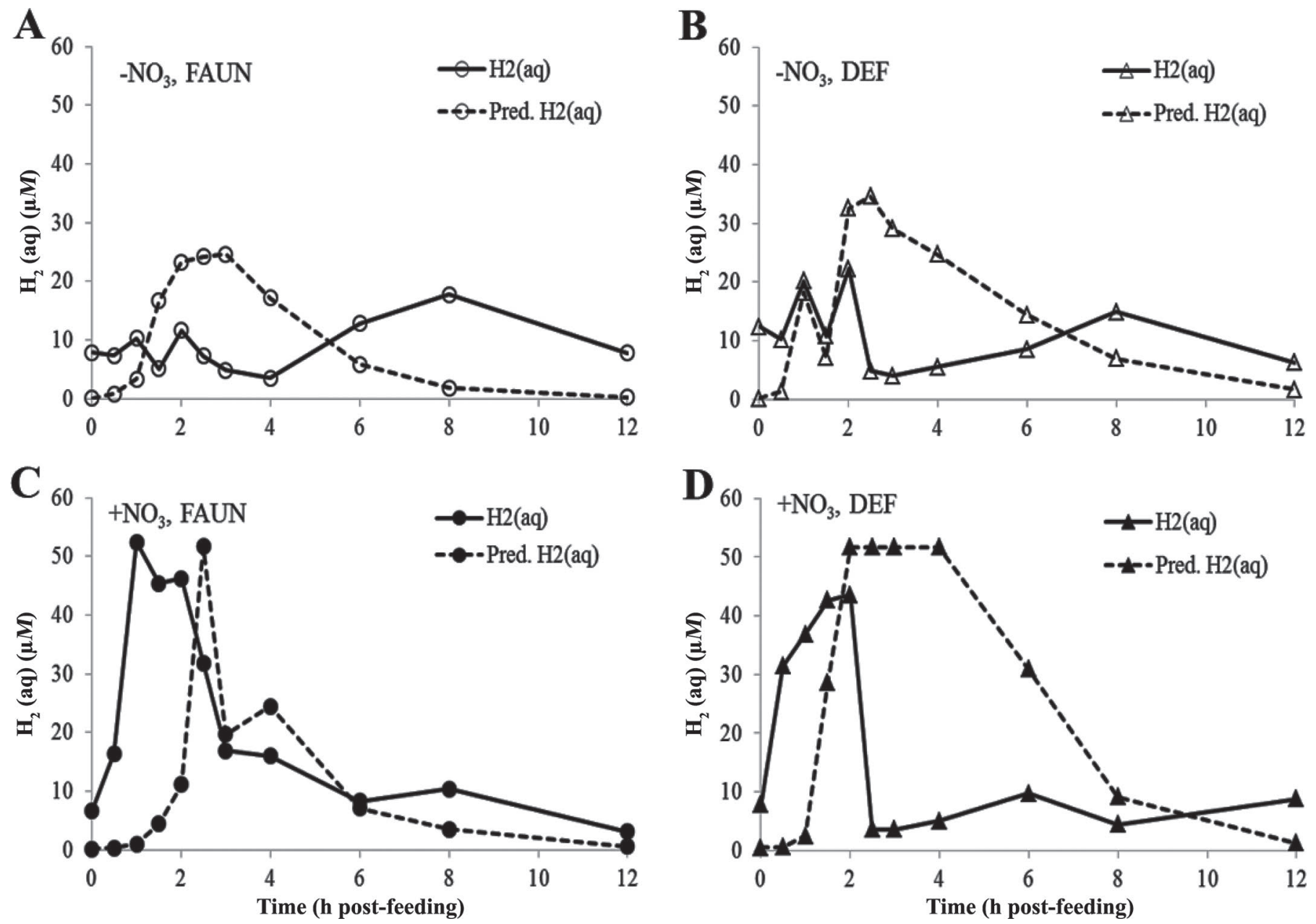

Figure 4. Pattern of predicted and observed aqueous hydrogen $\left[\mathrm{H}_{2}(\mathrm{aq})\right]$ during early fermentation post-feeding in continuous culture fermentors treated or not with $\mathrm{NO}_{3}{ }^{-}$and with or without defaunation. Treatments: $-\mathrm{NO}_{3}{ }^{-}=$no nitrate added, $+\mathrm{NO}_{3}{ }^{-}=$nitrate added at $1.5 \%$ of diet DM, FAUN = no defaunation, DEF = defaunated. Predicted (Pred.) $\mathrm{H}_{2}$ (aq) calculated from $\mathrm{H}_{2}$ detection in the headspace is represented by the dotted lines and measured $\mathrm{H}_{2}(\mathrm{aq})$ is represented by solid lines for each treatment.

supersaturation of $\mathrm{H}_{2}(\mathrm{aq})$ (Wang et al., 2016a,c) and highlights the importance for a direct measurement of $\mathrm{H}_{2}(\mathrm{aq})$ rather than estimating from partial pressure in the headspace (Wang et al., 2016b; Guyader et al., 2017; Wenner et al., 2017). Direct measurement of $\mathrm{H}_{2}(\mathrm{aq})$ is perhaps more important in rumen-cannulated animals from which gases can leak (Wang et al., 2019).

The increase in concentration of $\mathrm{H}_{2}(\mathrm{aq})$ in the present study probably resulted from $\mathrm{NO}_{3}{ }^{-}$reduction diverting $\mathrm{H}_{2}$ away from methanogenesis (Ungerfeld and Kohn, 2006). However, $\mathrm{NO}_{2}{ }^{-}$reduction is not nearly as broadly shared within the microbial community, and proximity of $\mathrm{NO}_{3}{ }^{-}$or $\mathrm{NO}_{2}{ }^{-}$reducers to $\mathrm{H}_{2}$ producers might be important (Leng, 2014). Also, removal of the remaining $\mathrm{H}_{2}$ may not be completed as quickly as it would be through the Wolfe cycle (Thauer, 2012), leading to accumulation of nitrite in the interim (Yang et al., 2016), as in Figure 1. Toxicity toward methanogens could also partially explain the increase in $\mathrm{H}_{2}(\mathrm{aq})$ with $+\mathrm{NO}_{3}{ }^{-}$treatments (Latham et al., 2016). If so, depressed disposal of reducing equivalents through $\mathrm{CH}_{4}$ should ultimately either directly decrease production of $\mathrm{H}_{2}$ or thermodynamically shift fermentation away from $\mathrm{H}_{2}$-producing acetate pathways.

An increase in $\mathrm{H}_{2}(\mathrm{aq})$ of even $10 \mu M$ (less than the main effect of $+\mathrm{NO}_{3}^{-}$in the present study) could be enough to increase the Gibbs free energy by approximately $30 \mathrm{~kJ} / \mathrm{mol}$ of glucose in the rumen and shift the stoichiometry of fermentation pathways (Ungerfeld and Kohn, 2006; Janssen, 2010). That the shift in $\mathrm{H}_{2}(\mathrm{aq})$ is substantial but not permanent throughout the day likely explains the minimal shift in daily average acetate: propionate (van Lingen et al., 2016). Increasing availability of $\mathrm{H}_{2}$ or electron donors did little to ameliorate 
the inhibition of soil methanogens by $\mathrm{NO}_{3}^{-}$(Roy and Conrad, 1999), and $\mathrm{NO}_{3}{ }^{-}$or $\mathrm{NO}_{2}{ }^{-}$directly inhibits rumen prokaryotes (Latham et al., 2016). Thus, the spike of $\mathrm{H}_{2}(\mathrm{aq})$ post-feeding might not just influence VFA production but instead affect VFA interconversions (Ungerfeld, 2015a) and direct $[2 \mathrm{H}]$ into cellular matter (Ungerfeld, 2015b), supporting the subsequent analysis of $\mathrm{H}$ recovery.

\section{Estimated H Recovery}

There was no interaction of $+\mathrm{NO}_{3}{ }^{-} \times \mathrm{DEF}$ nor an effect of DEF on $\mathrm{H}$ recovery $(P>0.10)$. The main effect of $+\mathrm{NO}_{3}{ }^{-}$decreased $(P<0.01) \mathrm{H}$ recovery by 16.6 percentage units if the reduction of $\mathrm{NO}_{3}{ }^{-}$was not taken into consideration ( $77.2 \%$ vs $60.5 \%$, SEM: 4.3$)$. However, there was no effect $(P>0.10)$ if $\mathrm{NO}_{3}{ }^{-}$reduction to either $\mathrm{NH}_{3}$ or $\mathrm{NO}_{2}^{-}$was factored into the estimates (77.2\% vs $78.6 \%$, SEM: 4.4). Nitrate inhibition of methanogenesis typically decreases $\mathrm{H}$ recovery (Lee and Beauchemin, 2014), perhaps resulting from an increased $\mathrm{H}_{2}(\mathrm{aq})$ concentration that increases escape into the headspace, increased production of formate (Olijhoek et al., 2016), or into major cellular products (Ungerfeld, 2015b); only $\mathrm{H}_{2}$ emission was measured in our study. Generally, $\mathrm{CH}_{4}$ mitigation decreases $\mathrm{H}$ recovery resulting from $\mathrm{H}_{2}$ emission (Ungerfeld, 2015b), which represents lost metabolizable energy (Morgavi et al., 2010; Lee and Beauchemin, 2014).

\section{Microbial Responses}

Quantification of total bacterial 16S rRNA gene copies revealed no main effect or interaction $(P>0.10)$ among treatments (Figure 5). The total archaeal 16S rRNA gene copies were not affected $(P>0.10)$ by the main effect of DEF or its interaction with $\mathrm{NO}_{3}{ }^{-}$. Methanogen abundance is inconsistently associated with methanogenesis (Tapio et al., 2017), partially due to a flexibility in efficiency of ATP generation coupled with $\mathrm{H}_{2}$ production (Thauer et al., 2008; Wallace et al., 2017). However, the main effect mean of $+\mathrm{NO}_{3}{ }^{-}$was $47 \%$ lower $(P<0.01)$ for total archaeal $16 \mathrm{~S}$ rRNA gene copies. Because methane production was $31 \%$ lower, $+\mathrm{NO}_{3}{ }^{-}$probably not only decreased methanogenesis by thermodynamic competition for $\mathrm{H}_{2}$ but also through inhibition of methanogens by $\mathrm{NO}_{3}{ }^{-}$or (more likely) $\mathrm{NO}_{2}^{-}$(Latham et al., 2016). Similar decreases in copies of methyl coenzyme $\mathrm{M}$ reductase $\mathrm{A}$ (a conserved gene involved in methanogenesis) were reported in dairy cows fed $\mathrm{NO}_{3}{ }^{-}$(Veneman et al., 2015).

Between 180 and 190 OTU were found in the fermentors (Supplemental Table S2; https://doi.org/10.3168/ jds.2020-18325), which is much lower than the richness reported for rumen samples (Meller et al., 2019) and for untreated continuous cultures (Salfer et al., 2018). Prokaryote population richness was not affected by treatment $(P>0.10)$, but measures of $\alpha$-diversity had an interaction with treatment $(P=0.05)$, whereby $-\mathrm{NO}_{3}{ }^{-}$/ $\mathrm{DEF}$ and $+\mathrm{NO}_{3}{ }^{-} / \mathrm{FAUN}$ had greater index values for both Shannon-Wiener and inverse Simpson diversities than $+\mathrm{NO}_{3}{ }^{-} / \mathrm{DEF}$ and $-\mathrm{NO}_{3}{ }^{-} / \mathrm{FAUN}$ (Supplemental Table S2). This decreased diversity may have led to greater sensitivity to the current treatment conditions due to decreased functional microbial redundancy. Analysis using Bray-Curtis dissimilarity (Supplemental Figure S1; https://doi.org/10.3168/jds.2020-18325) indicated no difference $(P>0.20)$ in overall microbiota for treatment, interaction of treatment, or fermentor; however, experimental periods 1 and 3 had uniquely different microbiota $(P<0.01)$ from periods 2 and 4 . The separation of microbial populations within continu-
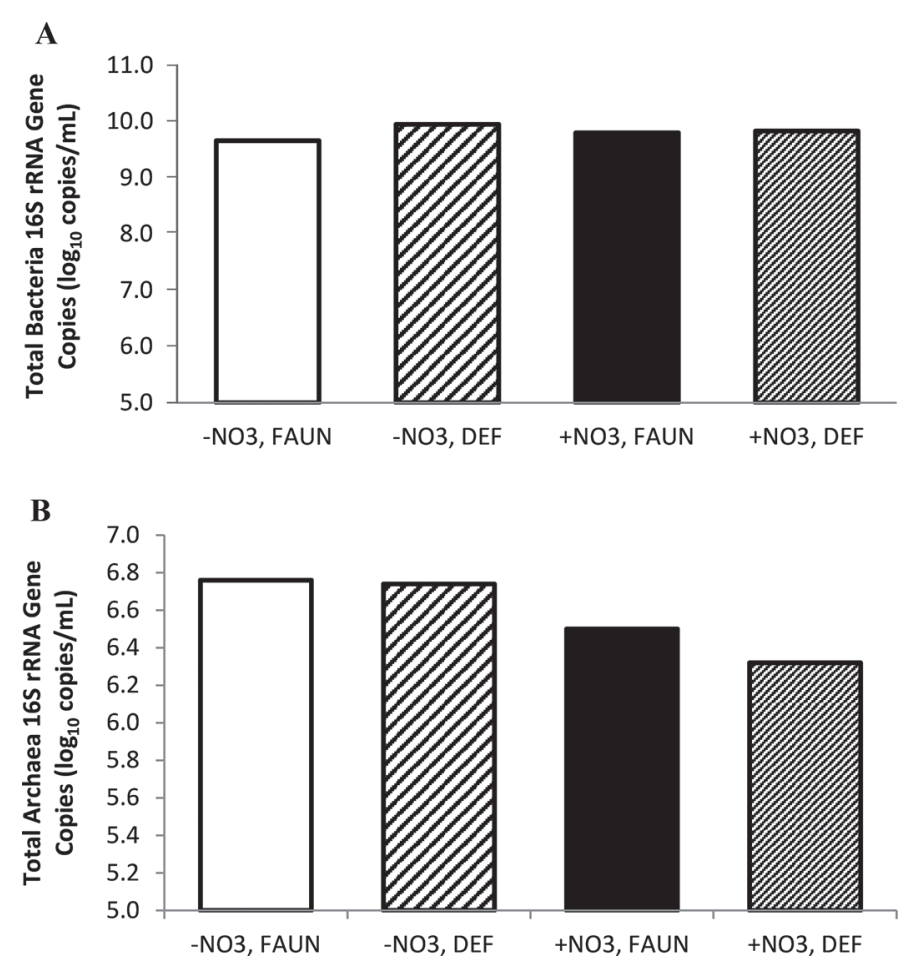

Figure 5. Quantification of total bacterial (A) and total archaeal (B) $16 \mathrm{~S}$ rRNA gene copies per $\mathrm{mL}$ by qPCR for continuous culture fermentors treated or not with $\mathrm{NO}_{3}^{-}$and with or without defaunation. Treatments: $-\mathrm{NO}_{3}{ }^{-}=$no nitrate added, $+\mathrm{NO}_{3}{ }^{-}=$nitrate added at $1.5 \%$ of diet DM, FAUN = no defaunation, DEF $=$ defaunated. Concentrations of $16 \mathrm{~S}$ rRNA gene copies are $\log _{10}$ transformed. There was no effect of treatment or interaction $(P>0.10)$ on total bacteria copies (pooled SEM: $0.11 \log _{10}$ copies $/ \mathrm{mL}$ ). There was no effect of DEF or interaction of $\mathrm{NO}_{3}{ }^{-} \times \operatorname{DEF}(P>0.10)$ on total archaea copies, but the main effect of $\mathrm{NO}_{3}{ }^{-}$decreased $(P<0.01)$ archaeal $16 \mathrm{~S}$ rRNA gene copies (pooled SEM: $0.09 \log _{10}$ copies $/ \mathrm{mL}$ ). 
ous culture fermentor periods has been documented in previous publications (Karnati et al., 2009b), probably due to continuous ecological successions, and accentuates the importance of sampling multiple cows.

Prokaryote phyla (Supplemental Table S2; https:// doi.org/10.3168/jds.2020-18325) represent the primary expected phyla within the rumen (Henderson et al., 2015). Among the phyla of archaea and bacteria detected, only Proteobacteria was decreased $(P=0.02)$ by DEF and tended to be increased $(P=0.09)$ by $+\mathrm{NO}_{3}{ }^{-}$(Supplemental Table S2). Some members of Proteobacteria are enriched in likely endosymbionts of protozoa (Park and Yu, 2018). The decreased proteobacterial relative abundance in DEF might be related to the decrease of protozoa-associated bacteria.

Part of the downward shift in Proteobacteria was mediated through genus Succinivibrio (Table 4) in which $+\mathrm{NO}_{3}^{-} /$FAUN was highest and $+\mathrm{NO}_{3}{ }^{-} / \mathrm{DEF}$ was lowest (interaction $P=0.09$ ). This genus increased dramatically within Epidinium caudatum 4 to 8 h postfeeding (Park and Yu, 2018). Succinivibrio numerically increased with the addition of $\mathrm{NO}_{3}{ }^{-}$at a dose similar to that (1.5\%) in the present study (Welty et al., 2019). Zhao et al. (2015) reported a quadratic increase in Succinivibrio in response to 1 or $2 \%$ added $\mathrm{NO}_{3}{ }^{-}$. Succinivibrio also increased in 1 of 2 studies with dairy cattle fed $\mathrm{NO}_{3}{ }^{-}$(Veneman et al., 2015) and in grazing steers supplemented with slow-release $\mathrm{NO}_{3}{ }^{-}$(Granja-Salcedo et al., 2019). The latter authors discussed succinateproducing bacteria like Succinivibrio harnessing $\mathrm{H}_{2^{-}}$ reducing power in fumarate reduction. However, one Succinivibrionaceae strain was documented to produce ATP via carboxylation of phosphoenolpyruvate and subsequent succinate formation using $[2 \mathrm{H}]$ derived from fermenting hexoses rather than from $\mathrm{H}_{2}(\mathrm{aq})$ (Pope et al., 2011). Therefore, the inverse relationship between methane production and Succinivibrionaceae abundance (Tapio et al., 2017) awaits further mechanistic explanation.

Within phylum Bacteroidetes, $+\mathrm{NO}_{3}{ }^{-}$interacted $(P$ $<0.05)$ with DEF to affect relative sequence abundance of uncultured genera RC9 Gut Group within family Rikenellaceae and uncultured genus within family S247 along with a trend $(P=0.06)$ for interaction in the uncultured rumen BS11 Gut Group (Table 4); all were highest for $+\mathrm{NO}_{3}^{-} / \mathrm{DEF}$. Welty et al. (2019) discussed the relative abundance of these or closely related genera to increase in abundance with dosing $\mathrm{NO}_{3}{ }^{-}$or live yeast, suggesting potential for nitrite reductase linked to electron transfer phosphorylation for ATP synthesis.

Within phylum Bacteroidetes, the Other RF16 genuslevel OTU tended $(P=0.06)$ to decrease in relative sequence abundance by the main effect of feeding
$\mathrm{NO}_{3}{ }^{-}$(Table 4). We know very little about this group currently; however, RF16 was associated with higher (77:23) than lower (49:51) forage:concentrate ratio (AlZahal et al., 2017). Within phylum Firmicutes, the insertae sedis in order Clostridiales $(P=0.08)$ and genus Butyrivibrio $(P=0.07)$ tended to be decreased by the main effect of $+\mathrm{NO}_{3}{ }^{-}$. Some Butyrivibrio were projected to reduce $\mathrm{NO}_{3}{ }^{-}$and $\mathrm{NO}_{2}{ }^{-}$(Latham et al., 2016), but others; namely, the characterized type strain of Butyrivibrio hungatei, are incapable of $\mathrm{NO}_{3}{ }^{-}$reduction (Kopečný et al., 2003). Other studies have shown no effect of supplemental $\mathrm{NO}_{3}{ }^{-}$on Butyrivibrio spp. (Zhao et al., 2015; Popova et al., 2017); however, these studies had far lower relative sequence abundance of Butyrivibrio than that in the present study. Dosing of $\mathrm{NO}_{3}{ }^{-}$depressed Butyrivibrio in continuous culture in a similar fashion (Welty et al., 2019). Potentially, the energy-conserving hydrogenase complex in many Butyrivibrio spp. (Hackmann and Firkins, 2015) might be interrupted by accumulating $\mathrm{H}_{2}(\mathrm{aq})$, but they also have a $\mathrm{Na}^{+}$-driven circuit to compensate (Schoelmerich et al., 2020). There were no significant increases in known nitrate-reducing bacteria such as Selenomonas, which agrees with results from dairy cattle (Veneman et al., 2015) and suggests $\mathrm{NO}_{3}{ }^{-}$or $\mathrm{NO}_{2}{ }^{-}$reductases distributed in other community members. Welty et al. (2019) discussed potential $\mathrm{NO}_{2}^{-}$reductase in the highly prevalent genus Prevotella and family Prevotellaceae, which increased in relative abundance along with other Bacteroidales genera. However, our study had no difference in these taxa, which decreased in vivo (Veneman et al., 2015; Granja-Salcedo et al., 2019).

Defaunation increased $(P=0.05)$ both uncultured Christensenellaceae and other Clostridiales and tended $(P=0.09)$ to increase uncultured Ruminococcaceae with phylum Firmicutes (Table 4). Using qPCR, Mosoni et al. (2011) reported that Ruminococcus albus and Ruminococcus flavefaciens increased in response to defaunation of sheep, hypothesizing a response to decreased predation; however, a more recent meta-analysis (Newbold et al., 2015) had the opposite relationship. Genus Ruminococcus (known cellulolytics) was unaffected, so the Ruminococcaceae affected herein probably occupy a different niche (e.g., amylolytic). Little is known about either Christensenellaceae or the RC9 Gut Group, but they were both reported to be among the most abundant unclassified bacterial OTU within the rumen (Seshadri et al., 2018). Perhaps, either or both of these groups are closely related to the roles filled by protozoa (e.g., amylolytic). Several members of the RC9 Gut Group decreased in relative abundance in cows switched from corn silage-based TMR to fresh pasture (Schären et al., 2017). 
Table 4. Relative sequence abundance of prokaryote genera sorted by phyla ${ }^{1}$

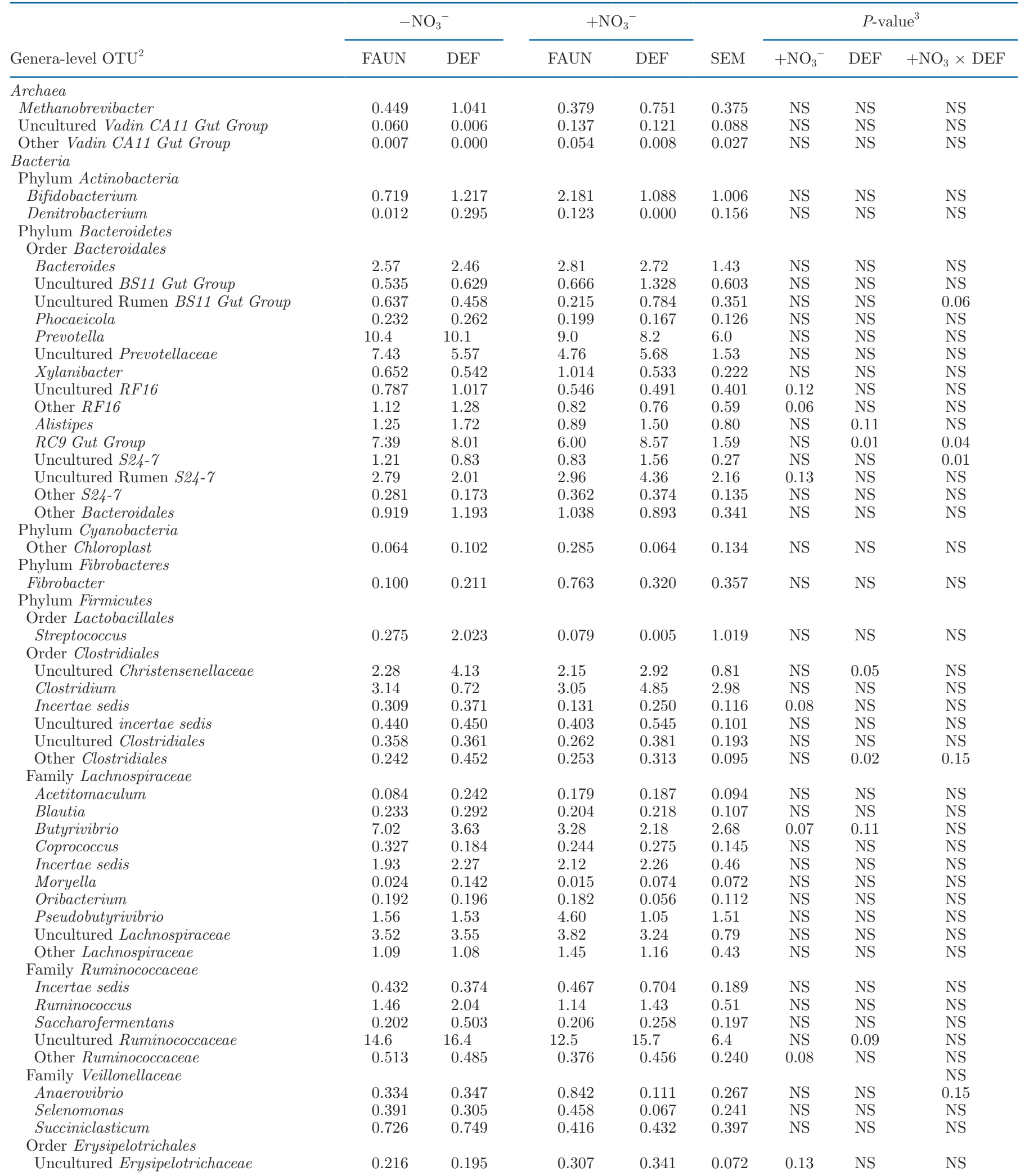


Table 4 (Continued). Relative sequence abundance of prokaryote genera sorted by phyla ${ }^{1}$

\begin{tabular}{|c|c|c|c|c|c|c|c|c|}
\hline Genera-level OTU² & \multicolumn{2}{|c|}{$-\mathrm{NO}_{3}^{-}$} & \multicolumn{2}{|c|}{$+\mathrm{NO}_{3}^{-}$} & SEM & \multicolumn{3}{|c|}{$P$-value ${ }^{3}$} \\
\hline \multicolumn{9}{|l|}{ Phylum Proteobacteria } \\
\hline Succinivibrio & 0.422 & 0.269 & 1.765 & 0.287 & 0.387 & 0.08 & 0.05 & 0.09 \\
\hline Uncultured Succinivibrionaceae & 1.05 & 0.27 & 0.85 & 0.39 & 0.58 & NS & 0.15 & NS \\
\hline \multicolumn{9}{|l|}{ Phylum Spirochaetes } \\
\hline \multicolumn{9}{|l|}{ Phylum Tenericutes } \\
\hline Anaeroplasma & 0.447 & 0.218 & 0.422 & 0.250 & 0.194 & NS & 0.12 & NS \\
\hline \multicolumn{9}{|l|}{ Phylum Verrucomicrobia } \\
\hline Akkermansia & 0.080 & 0.286 & 0.119 & 0.065 & 0.128 & NS & NS & NS \\
\hline Unassigned & 11.8 & 10.8 & 15.2 & 14.3 & 3.1 & NS & NS & NS \\
\hline
\end{tabular}

${ }^{1}$ Treatments: $-\mathrm{NO}_{3}{ }^{-}=$no nitrate added, $+\mathrm{NO}_{3}{ }^{-}=$nitrate added at $1.5 \%$ diet DM, FAUN $=$ no defaunation, DEF $=$ defaunated.

${ }^{2}$ Operational taxonomic units are included in this table only if one measurement had $\geq 0.50 \%$ relative abundance.

${ }^{3} P$-values reported for the main effects of $+\mathrm{NO}_{3}{ }^{-}, \mathrm{DEF}$, and their interaction. $\mathrm{NS}=P>0.15$.

\section{CONCLUSIONS}

Expectations for $\mathrm{NO}_{3}^{-}$to suppress methanogenesis are corroborated in the present study, but increased concentration of $\mathrm{H}_{2}(\mathrm{aq})$ and escape of gaseous $\mathrm{H}_{2}$ explained previous observations for the poor response in ME by ruminants fed $\mathrm{NO}_{3}{ }^{-}$for $\mathrm{CH}_{4}$ mitigation. Meanwhile, the lack of effect of DEF adds to the known complexity of protozoal contribution to methanogenesis via symbiotic methanogens. Shifts in propionate, valerate, and branched-chain VFA with DEF are contrary to previous studies in continuous culture and in vivo, but this result could point to the importance of other dietary factors unique to continuous culture fermentors rather than a clear responsibility of protozoa. Under our culture conditions, the removal of protozoa had little effect on the nitrate-reducing capacity or methanogenic symbiosis with $\mathrm{H}_{2}$ producers. More work is needed to better explain the complex relationship of protozoa with other microbial community members in the rumen under diverse fermentative conditions. The use of continuous cultures and $\mathrm{NO}_{3}{ }^{-}$as an alternate electron sink provide a valuable model for future research to investigate the complexities of microbial interactions affecting fermentation stoichiometry in the rumen.

\section{ACKNOWLEDGMENTS}

Research was jointly supported by state and federal funds appropriated to the Ohio Agricultural Research and Development Center, The Ohio State University. Funds were provided by the USDA National Institute of Food and Agriculture (Washington, DC; award 201267015-19437). We express our gratitude to Dr. Lindsey Solden, formerly of the Wrighton Microbiology Laboratory at Ohio State University, for her assistance with data processing of microbial sequencing results, and to C. Gasser and S. Harp (Department of Animal Sciences, Ohio State University) for their assistance with the conduct of the experiment. We also acknowledge the unmatched expertise of our colleague Burk Dehority, who provided helpful counsel to the end. The authors have not stated any conflicts of interest.

\section{REFERENCES}

Alaboudi, A. R., and G. A. Jones. 1985. Effect of acclimation to high nitrate intakes on some rumen fermentation parameters in sheep. Can. J. Anim. Sci. 65:841-849. https://doi.org/10.4141/cjas85 -099 .

AlZahal, O., F. Li, L. L. Guan, N. D. Walker, and B. W. McBride. 2017. Factors influencing ruminal bacterial community diversity and composition and microbial fibrolytic enzyme abundance in lactating dairy cows with a focus on the role of active dry yeast. J. Dairy Sci. 100:4377-4393. https://doi.org/10.3168/jds.2016-11473.

AOAC. 1990. Official Methods of Analysis. 15th ed. Assoc. Off. Anal. Chem., Arlington, VA.

Belanche, A., G. de la Fuente, and C. J. Newbold. 2014. Study of methanogen communities associated with different rumen protozoal populations. FEMS Microbiol. Ecol. 90:663-677. https://doi .org/10.1111/1574-6941.12423.

Caporaso, J. G., J. Kuczynski, J. Stombaugh, K. Bittinger, F. D. Bushman, E. K. Costello, N. Fierer, A. G. Peña, J. K. Goodrich, J. I. Gordon, G. A. Huttley, S. T. Kelley, D. Knights, J. E. Koenig, R. E. Ley, C. A. Lozupone, D. McDonald, B. D. Muegge, M. Pirrung, J. Reeder, J. R. Sevinsky, P. J. Turnbaugh, W. A. Walters, J. Widmann, T. Yatsunenko, J. Zaneveld, and R. Knight. 2010. Qiime allows analysis of high-throughput community sequencing data. Nat. Methods 7:335-336. https://doi.org/10.1038/nmeth.f .303.

Chaney, A. L., and E. P. Marbach. 1962. Modified reagents for determination of urea and ammonia. Clin. Chem. 8:130-132. https:// doi.org/10.1093/clinchem/8.2.130.

Dehority, B. A. 1993. Laboratory Manual for Classification and Morphology of Rumen Ciliate Protozoa. CRC Press Inc., Boca Raton, FL.

Dehority, B. A. 2010. Physiological characteristics of several rumen protozoa grown in vitro with observations on within and among species variation. Eur. J. Protistol. 46:271-279. https://doi.org/10 $.1016 /$ j.ejop.2010.05.002. 
Demeyer, D. I., and C. J. Van Nevel. 1979. Effect of defaunation on the metabolism of rumen micro-organisms. Br. J. Nutr. 42:515524. https://doi.org/10.1079/BJN19790143.

Edgar, R. C. 2013. Uparse: Highly accurate OTU sequences from microbial amplicon reads. Nat. Methods 10:996-998. https://doi.org/ $10.1038 /$ nmeth. 2604

Edwards, J. E., R. J. Forster, T. M. Callaghan, V. Dollhofer, S. S. Dagar, Y. Cheng, J. Chang, S. Kittelmann, K. Fliegerova, A. K. Puniya, J. K. Henske, S. P. Gilmore, M. A. O'Malley, G. W. Griffith, and H. Smidt. 2017. PCR and omics based techniques to study the diversity, ecology and biology of anaerobic fungi: Insights, challenges and opportunities. Front. Microbiol. 8:1657. https://doi.org/10.3389/fmicb.2017.01657.

Eugène, M., H. Archimède, and D. Sauvant. 2004. Quantitative metaanalysis on the effects of defaunation of the rumen on growth, intake and digestion in ruminants. Livest. Prod. Sci. 85:81-97. https: //doi.org/10.1016/S0301-6226(03)00117-9.

Faulkner, M. J., B. A. Wenner, L. M. Solden, and W. P. Weiss. 2017. Source of supplemental dietary copper, zinc, and manganese affects fecal microbial relative abundance in lactating dairy cows. J. Dairy Sci. 100:1037-1044. https://doi.org/10.3168/jds.2016-11680.

Fowler, C. M., J. E. Plank, E. Devillard, B. J. Bequette, and J. L. Firkins. 2015. Assessing the ruminal action of the isopropyl ester of 2-hydroxy-4-(methylthio) butanoic acid (HMBi) in continuous and batch cultures of mixed ruminal microbes. J. Dairy Sci. 98:11671177. https://doi.org/10.3168/jds.2014-8692.

Granja-Salcedo, Y. T., R. M. Fernandes, R. C. Araujo, L. T. Kishi, T. T. Berchielli, F. D. Resende, A. Berndt, and G. R. Siqueira. 2019. Long-term encapsulated nitrate supplementation modulates rumen microbial diversity and rumen fermentation to reduce methane emission in grazing steers. Front. Microbiol. 10:614. https:// doi.org/10.3389/fmicb.2019.00614.

Greening, C., R. Geier, C. Wang, L. C. Woods, S. E. Morales, M. J. McDonald, R. Rushton-Green, X. C. Morgan, S. Koike, S. C. Leahy, W. J. Kelly, I. Cann, G. T. Attwood, G. M. Cook, and R. I. Mackie. 2019. Diverse hydrogen production and consumption pathways influence methane production in ruminants. ISME J. 13:2617-2632. https://doi.org/10.1038/s41396-019-0464-2.

Guyader, J., M. Eugene, M. Doreau, D. P. Morgavi, C. Gerard, C. Loncke, and C. Martin. 2015. Nitrate but not tea saponin feed additives decreased enteric methane emissions in nonlactating cows. J. Anim. Sci. 93:5367-5377. https://doi.org/10.2527/jas.2015 $-9367$.

Guyader, J., M. Eugene, P. Noziere, D. P. Morgavi, M. Doreau, and C. Martin. 2014. Influence of rumen protozoa on methane emission in ruminants: A meta-analysis approach. Animal 8:1816-1825. https: //doi.org/10.1017/S1751731114001852.

Guyader, J., E. M. Ungerfeld, and K. A. Beauchemin. 2017. Redirection of metabolic hydrogen by inhibiting methanogenesis in the rumen simulation technique (RUSITEC). Front. Microbiol. 8:393. https://doi.org/10.3389/fmicb.2017.00393.

Hackmann, T. J., and J. Firkins. 2015. Electron transport phosphorylation in rumen butyrivibrios: Unprecedented ATP yield for glucose fermentation to butyrate. Front. Microbiol. 6:622. https://doi .org/10.3389/fmicb.2015.00622.

Hackstein, J. H. P., and A. G. M. Tielens. 2010. Hydrogenosomes. Pages 175-206 in (Endo)symbiotic Methanogenic Archaea. J. H. P. Hackstein, ed. Springer-Verlag, Heidelberg, Germany.

Harvatine, D. I., J. L. Firkins, and M. L. Eastridge. 2002. Whole linted cottonseed as a forage substitute fed with ground or steam-flaked corn: Digestibility and performance. J. Dairy Sci. 85:1976-1987. https://doi.org/10.3168/jds.S0022-0302(02)74274-4.

Hegarty, R. S., S. H. Bird, B. A. Vanselow, and R. Woodgate. 2008. Effects of the absence of protozoa from birth or from weaning on the growth and methane production of lambs. Br. J. Nutr. 100:1220-1227. https://doi.org/10.1017/S0007114508981435.

Hegarty, R. S., and R. Gerdes. 1999. Hydrogen production and transfer in the rumen. Recent Adv. Anim. Nutr. Aust. 12:37.

Henderson, G., F. Cox, S. Ganesh, A. Jonker, W. Young, and P. H. Janssen. 2015. Rumen microbial community composition varies with diet and host, but a core microbiome is found across a wide geographical range. Sci. Rep. 5:14567. https://doi.org/10.1038/ srep14567.

Hoover, W. H., B. A. Crooker, and C. J. Sniffen. 1976. Effects of differential solid-liquid removal rates on protozoa numbers in continous cultures of rumen contents. J. Anim. Sci. 43:528-534. https://doi . org $/ 10.2527 /$ jas1976.432528x.

Hristov, A. N., and J.-P. Jouany. 2005. Factors affecting the efficiency of nitrogen utilization in the rumen. Pages 117-166 in Nitrogen and phosphorus nutrition of cattle and environment. A. N. Hristov and E. Pfeffer, ed. CAB International, Wallingford, UK.

Janssen, P. H. 2010. Influence of hydrogen on rumen methane formation and fermentation balances through microbial growth kinetics and fermentation thermodynamics. Anim. Feed Sci. Technol. 160:1-22. https://doi.org/10.1016/j.anifeedsci.2010.07.002.

Jouany, J. P., and K. Ushida. 1999. The role of protozoa in feed digestion. Am. J. Appl. Sci. 12:113-128.

Karnati, S. K. R., J. T. Sylvester, C. V. D. M. Ribeiro, L. E. Gilligan, and J. L. Firkins. 2009a. Investigating unsaturated fat, monensin, or bromoethanesulfonate in continuous cultures retaining ruminal protozoa. I. Fermentation, biohydrogenation, and microbial protein synthesis. J. Dairy Sci. 92:3849-3860. https://doi.org/10 $.3168 /$ jds.2008-1436.

Karnati, S. K. R., Z. Yu, and J. L. Firkins. 2009b. Investigating unsaturated fat, monensin, or bromoethanesulfonate in continuous cultures retaining ruminal protozoa. II. Interaction of treatment and presence of protozoa on prokaryotic communities. J. Dairy Sci. 92:3861-3873. https://doi.org/10.3168/jds.2008-1437.

Kopečný, J., M. Zorec, J. Mrázek, Y. Kobayashi, and R. MarinšekLogar. 2003. Butyrivibrio hungatei sp. nov. and Pseudobutyrivibrio xylanivorans sp. nov., butyrate-producing bacteria from the rumen. Int. J. Syst. Evol. Microbiol. 53:201-209. https://doi.org/10 .1099 /ijs.0.02345-0.

Latham, E. A., R. C. Anderson, W. E. Pinchak, and D. J. Nisbet. 2016. Insights on alterations to the rumen ecosystem by nitrate and nitrocompounds. Front. Microbiol. 7:228. https://doi.org/10 $.3389 /$ fmicb.2016.00228.

Leahy, S. C., W. J. Kelly, E. Altermann, R. S. Ronimus, C. J. Yeoman, D. M. Pacheco, D. Li, Z. Kong, S. McTavish, C. Sang, S. C. Lambie, P. H. Janssen, D. Dey, and G. T. Attwood. 2010. The genome sequence of the rumen methanogen Methanobrevibacter ruminantium reveals new possibilities for controlling ruminant methane emissions. PLoS One 5:e8926. https://doi.org/10.1371/ journal.pone.0008926.

Lee, C., and K. A. Beauchemin. 2014. A review of feeding supplementary nitrate to ruminant animals: Nitrate toxicity, methane emissions, and production performance. Can. J. Anim. Sci. 94:557-570. https://doi.org/10.4141/cjas-2014-069.

Leng, R. A. 2014. Interactions between microbial consortia in biofilms: A paradigm shift in rumen microbial ecology and enteric methane mitigation. Anim. Prod. Sci. 54:519-543. https://doi.org/10.1071/ AN13381.

Lin, M., D. M. Schaefer, W. S. Guo, L. P. Ren, and Q. X. Meng. 2011. Comparisons of in vitro nitrate reduction, methanogenesis, and fermentation acid profile among rumen bacterial, protozoal and fungal fractions. Asian-Australas. J. Anim. Sci. 24:471-478. https: //doi.org/10.5713/ajas.2011.10288.

Machmüller, A., C. R. Soliva, and M. Kreuzer. 2003. Effect of coconut oil and defaunation treatment on methanogenesis in sheep. Reprod. Nutr. Dev. 43:41-55. https://doi.org/10.1051/rnd:2003005.

Meller, R. A., B. A. Wenner, J. Ashworth, A. M. Gehman, J. Lakritz, and J. L. Firkins. 2019. Potential roles of nitrate and live yeast culture in suppressing methane emission and influencing ruminal fermentation, digestibility, and milk production in lactating jersey cows. J. Dairy Sci. 102:6144-6156. https://doi.org/10.3168/ jds.2018-16008.

Morgavi, D. P., E. Forano, C. Martin, and C. J. Newbold. 2010. Microbial ecosystem and methanogenesis in ruminants. Animal 4:10241036. https://doi.org/10.1017/S1751731110000546.

Morgavi, D. P., C. Martin, J.-P. Jouany, and M. J. Ranilla. 2012. Rumen protozoa and methanogenesis: Not a simple cause-effect 
relationship. Br. J. Nutr. 107:388-397. https://doi.org/10.1017/ S0007114511002935.

Mosoni, P., C. Martin, E. Forano, and D. P. Morgavi. 2011. Long-term defaunation increases the abundance of cellulolytic ruminococci and methanogens but does not affect the bacterial and methanogen diversity in the rumen of sheep. J. Anim. Sci. 89:783-791. https://doi.org/10.2527/jas.2010-2947.

Newbold, C. J., D. G. Chamberlain, and A. G. Williams. 1986. The effects of defaunation on the metabolism of lactic acid in the rumen. J. Sci. Food Agric. 37:1083-1090. https://doi.org/10.1002/ jsfa. 2740371105 .

Newbold, C. J., G. de la Fuente, A. Belanche, E. Ramos-Morales, and N. R. McEwan. 2015. The role of ciliate protozoa in the rumen. Front. Microbiol. 6:1313. https://doi.org/10.3389/fmicb.2015 .01313 .

Nolan, J. V., R. S. Hegarty, J. Hegarty, I. R. Godwin, and R. Woodgate. 2010. Effects of dietary nitrate on fermentation, methane production and digesta kinetics in sheep. Anim. Prod. Sci. 50:801806. https://doi.org/10.1071/AN09211.

O'Dell, J. W. 1993. Determination of nitrate-nitrite by automated colorimetry. Environmental Monitoring Systems Laboratory, US Environmental Protection Agency, Cincinnati, $\mathrm{OH}$.

Olijhoek, D. W., A. L. F. Hellwing, M. Brask, M. R. Weisbjerg, O. Højberg, M. K. Larsen, J. Dijkstra, E. J. Erlandsen, and P. Lund. 2016. Effect of dietary nitrate level on enteric methane production, hydrogen emission, rumen fermentation, and nutrient digestibility in dairy cows. J. Dairy Sci. 99:6191-6205. https://doi.org/10 $.3168 /$ jds.2015-10691.

Park, T., and Z. Yu. 2018. Do ruminal ciliates select their preys and prokaryotic symbionts? Front. Microbiol. 9:1710. https://doi.org/ 10.3389/fmicb.2018.01710.

Patra, A. K., and Z. Yu. 2013. Effective reduction of enteric methane production by a combination of nitrate and saponin without adverse effect on feed degradability, fermentation, or bacterial and archaeal communities of the rumen. Bioresour. Technol. 148:352360. https://doi.org/10.1016/j.biortech.2013.08.140.

Pope, P. B., W. Smith, S. E. Denman, S. G. Tringe, K. Barry, P. Hugenholtz, C. S. McSweeney, A. C. McHardy, and M. Morrison. 2011. Isolation of Succinovibrionaceae implicated in low methane emissions from Tammar wallabies. Science 333:646-648. https:// doi.org/10.1126/science.1205760.

Popova, M., E. McGovern, M. S. McCabe, C. Martin, M. Doreau, M. Arbre, S. J. Meale, D. P. Morgavi, and S. M. Waters. 2017. The structural and functional capacity of ruminal and cecal microbiota in growing cattle was unaffected by dietary supplementation of linseed oil and nitrate. Front. Microbiol. 8:937. https://doi.org/10 $.3389 /$ fmicb.2017.00937.

Quast, C., E. Pruesse, P. Yilmaz, J. Gerken, T. Schweer, and P. Yarza. 2013. The SILVA ribosomal RNA gene database project: Improved data processing and web-based tools. Nucleic Acids Res. 41:D590D596.

Roman-Garcia, Y., B. A. Wenner, C. M. Welty, B. K. Wagner, J. E. Plank, R. A. Meller, S. J. Waits, A. M. Gehman, and J. L. Firkins. 2019. Rumen microbial responses to supplemental nitrate. I. Yeast growth and protozoal chemotaxis in vitro as affected by nitrate and nitrite concentrations. J. Dairy Sci. 102:2207-2216. https:// doi.org/10.3168/jds.2018-15274.

Roy, R., and R. Conrad. 1999. Effect of methanogenic precursors (acetate, hydrogen, propionate) on the suppression of methane production by nitrate in anoxic rice field soil. FEMS Microbiol. Ecol. 28:49-61. https://doi.org/10.1111/j.1574-6941.1999.tb00560.x.

Salfer, I. J., C. Staley, H. E. Johnson, M. J. Sadowsky, and M. D. Stern. 2018. Comparisons of bacterial and archaeal communities in the rumen and a dual-flow continuous culture fermentation system using amplicon sequencing. J. Anim. Sci. 96:1059-1072. https:// doi.org/10.1093/jas/skx056.

Schären, M., C. Drong, K. Kiri, S. Riede, M. Gardener, U. Meyer, J. Hummel, T. Urich, G. Breves, and S. Dänicke. 2017. Differential effects of monensin and a blend of essential oils on rumen microbiota composition of transition dairy cows. J. Dairy Sci. 100:27652783. https://doi.org/10.3168/jds.2016-11994.
Schoelmerich, M. C., A. Katsyv, J. Dönig, T. J. Hackmann, and V. Müller. 2020. Energy conservation involving 2 respiratory circuits. Proc. Natl. Acad. Sci. USA 117:1167-1173. https://doi.org/10 $.1073 /$ pnas.1914939117.

Seshadri, R., S. C. Leahy, G. T. Attwood, K. H. Teh, S. C. Lambie, A. L. Cookson, E. A. Eloe-Fadrosh, G. A. Pavlopoulos, M. Hadjithomas, N. J. Varghese, D. Paez-Espino, R. Perry, G. Henderson, C. J. Creevey, N. Terrapon, P. Lapebie, E. Drula, V. Lombard, E. Rubin, N. C. Kyrpides, B. Henrissat, T. Woyke, N. N. Ivanova, and W. J. Kelly. 2018. Cultivation and sequencing of rumen microbiome members from the Hungate1000 collection. Nat. Biotechnol. 36:359-367. https://doi.org/10.1038/nbt.4110.

Stiverson, J., M. Morrison, and Z. Yu. 2011. Populations of select cultured and uncultured bacteria in the rumens of sheep and the effects of diets and ruminal fractions. Int. J. Microbiol. 2011:750613. https://doi.org/10.1155/2011/750613.

Sylvester, J. T. 2005. Development and evaluation of new techniques to quantify ruminal pool size and duodenal flow of protozoal nitrogen. PhD Diss. The Ohio State University, Columbus.

Sylvester, J. T. S. K. R. Karnati, Z. Yu, C. J. Newbold, and J. L. Firkins. 2005. Evaluation of a real-time PCR assay for measuring the ruminal pool and duodenal flow of protozoal nitrogen. J. Dairy Sci. 88:2083-2095. https://doi.org/10.3168/jds.S0022 -0302(05) 72885-X.

Tapio, I., T. J. Snelling, F. Strozzi, and R. J. Wallace. 2017. The ruminal microbiome associated with methane emissions from ruminant livestock. J. Anim. Sci. Biotechnol. 8:7. https://doi.org/10.1186/ s40104-017-0141-0.

Thauer, R. K. 2012. The Wolfe cycle comes full circle. Proc. Natl. Acad. Sci. USA 109:15084-15085. https://doi.org/10.1073/pnas .1213193109 .

Thauer, R. K., A.-K. Kaster, H. Seedorf, W. Buckel, and R. Hedderich. 2008. Methanogenic archaea: Ecologically relevant differences in energy conservation. Nat. Rev. Microbiol. 6:579-591. https:/ /doi.org/10.1038/nrmicro1931.

Ungerfeld, E. M. 2015a. Limits to dihydrogen incorporation into electron sinks alternative to methanogenesis in ruminal fermentation. Front. Microbiol. 6:1272. https://doi.org/10.3389/fmicb.2015 .01272 .

Ungerfeld, E. M. 2015b. Shifts in metabolic hydrogen sinks in the methanogenesis-inhibited ruminal fermentation: A meta-analysis. Front. Microbiol. 6:37. https://doi.org/10.3389/fmicb.2015.00037.

Ungerfeld, E. M. 2018. Inhibition of rumen methanogenesis and ruminant productivity: A meta-analysis. Front. Vet. Sci. 5:113. https:/ /doi.org/10.3389/fvets.2018.00113

Ungerfeld, E. M., and R. A. Kohn. 2006. The role of thermodynamics in the control of ruminal fermentation. Pages 55-86 in Ruminant physiology: Digestion, metabolism and impact of nutrition on gene expression, immunology and stress. K. Sejrsen, T. Hvelplund, and M. O. Nielsen, ed. Wageningen Academic Publishers, Wageningen, the Netherlands.

US EPA (Environmental Protection Agency). 2013. Inventory of U.S. Greenhous Gas Emissions and Sinks: 1990-2011. US EPA, Washington, DC.

Ushida, K. 2010. Symbiotic methanogens and rumen ciliates. Pages 25-34 in (Endo)symbiotic Methanogenic Archaea. J. H. P. Hackstein, ed. Springer-Verlag, Heidelberg, Germany.

Valle, E. R., G. Henderson, P. H. Janssen, F. Cox, T. W. Alexander, and T. A. McAllister. 2015. Considerations in the use of fluorescence in situ hybridization (FISH) and confocal laser scanning microscopy to characterize rumen methanogens and define their spatial distributions. Can. J. Microbiol. 61:417-428. https://doi .org/10.1139/cjm-2014-0873.

van Lingen, H. J., C. M. Plugge, J. G. Fadel, E. Kebreab, A. Bannink, and J. Dijkstra. 2016. Thermodynamic driving force of hydrogen on rumen microbial metabolism: A theoretical investigation. PLoS One 11:e0161362. https://doi.org/10.1371/journal.pone.0161362.

Van Soest, P. J., J. B. Robertson, and B. A. Lewis. 1991. Methods for dietary fiber, neutral detergent fiber, and nonstarch polysaccharides in relation to animal nutrition. J. Dairy Sci. 74:3583-3597. https://doi.org/10.3168/jds.S0022-0302(91)78551-2. 
van Zijderveld, S. M., B. Fonken, J. Dijkstra, W. J. J. Gerrits, H. B. Perdok, W. Fokkink, and J. R. Newbold. 2011a. Effects of a combination of feed additives on methane production, diet digestibility, and animal performance in lactating dairy cows. J. Dairy Sci. 94:1445-1454. https://doi.org/10.3168/jds.2010-3635.

van Zijderveld, S. M., W. J. J. Gerrits, J. A. Apajalahti, J. R. Newbold, J. Dijkstra, R. A. Leng, and H. B. Perdok. 2010. Nitrate and sulfate: Effective alternative hydrogen sinks for mitigation of ruminal methane production in sheep. J. Dairy Sci. 93:5856-5866. https://doi.org/10.3168/jds.2010-3281.

van Zijderveld, S. M., W. J. J. Gerrits, J. Dijkstra, J. R. Newbold, R. B. A. Hulshof, and H. B. Perdok. 2011b. Persistency of methane mitigation by dietary nitrate supplementation in dairy cows. J. Dairy Sci. 94:4028-4038. https://doi.org/10.3168/jds.2011-4236.

Veneman, J. B., S. Muetzel, K. J. Hart, C. L. Faulkner, J. M. Moorby, H. B. Perdok, and C. J. Newbold. 2015. Does dietary mitigation of enteric methane production affect rumen function and animal productivity in dairy cows? PLoS One 10:e0140282. https://doi .org/10.1371/journal.pone.0140282.

Wagner, B. K., B. A. Wenner, J. E. Plank, G. D. Poppy, and J. L. Firkins. 2018. Investigation of ammonium lactate supplementation on fermentation end products and bacterial assimilation of nitrogen in dual-flow continuous culture. J. Dairy Sci. 101:8032-8045. https:/ /doi.org/10.3168/jds.2017-14358.

Wallace, R. J., T. J. Snelling, C. A. McCartney, I. Tapio, and F. Strozzi. 2017. Application of meta-omics techniques to understand greenhouse gas emissions originating from ruminal metabolism. Genet. Sel. Evol. 49:9. https://doi.org/10.1186/s12711-017-0285-6.

Wang, M., E. M. Ungerfeld, R. Wang, C. S. Zhou, Z. Z. Basang, S. M. Ao, and Z. L. Tan. 2016a. Supersaturation of dissolved hydrogen and methane in rumen of Tibetan sheep. Front. Microbiol. 7:850. https://doi.org/10.3389/fmicb.2016.00850.

Wang, M., R. Wang, P. H. Janssen, X. M. Zhang, X. Z. Sun, D. Pacheco, and Z. L. Tan. 2016b. Sampling procedure for the measurement of dissolved hydrogen and volatile fatty acids in the rumen of dairy cows. J. Anim. Sci. 94:1159-1169. https://doi.org/10.2527/ jas.2015-9658.

Wang, M., R. Wang, T. Y. Xie, P. H. Janssen, X. Z. Sun, K. A. Beauchemin, Z. L. Tan, and M. Gao. 2016c. Shifts in rumen fermentation and microbiota are associated with dissolved ruminal hydrogen concentrations in lactating dairy cows fed different types of carbohydrates. J. Nutr. 146:1714-1721. https://doi.org/10 $.3945 /$ jn.116.232462.

Wang, R., M. Wang, E. M. Ungerfeld, X. M. Zhang, D. L. Long, H. X. Mao, J. P. Deng, A. Bannink, and Z. L. Tan. 2018. Nitrate improves ammonia incorporation into rumen microbial protein in lactating dairy cows fed a low-protein diet. J. Dairy Sci. 101:97899799. https://doi.org/10.3168/jds.2018-14904.

Wang, R., M. Wang, X. M. Zhang, J. N. Wen, Z. Y. Ma, D. L. Long, J. P. Deng, and Z. L. Tan. 2019. Effects of rumen cannulation on dissolved gases and methanogen community in dairy cows. J. Dairy Sci. 102:2275-2282. https://doi.org/10.3168/jds.2018-15187.
Weller, R. A., and A. F. Pilgrim. 1974. Passage of protozoa and volatile fatty acids from the rumen of the sheep and from a continuous in vitro fermentation system. Br. J. Nutr. 32:341-351. https://doi .org/10.1079/BJN19740087.

Welty, C. M., B. A. Wenner, B. K. Wagner, Y. Roman-Garcia, J. E. Plank, R. A. Meller, A. M. Gehman, and J. L. Firkins. 2019 Rumen microbial responses to supplemental nitrate. II. Potential interactions with live yeast culture on the prokaryotic community and methanogenesis in continuous culture. J. Dairy Sci. 102:22172231. https://doi.org/10.3168/jds.2018-15826.

Wenner, B. A., J. de Souza, F. Batistel, T. J. Hackmann, Z. Yu, and J. L. Firkins. 2017. Association of aqueous hydrogen concentration with methane production in continuous cultures modulated to vary $\mathrm{pH}$ and solids passage rate. J. Dairy Sci. 100:5378-5389. https://doi.org/10.3168/jds.2016-12332.

Whitelaw, F. G., J. M. Eadie, L. A. Bruce, and W. J. Shand. 1984 Methane formation in faunated and ciliate-free cattle and its relationship with rumen volatile fatty acid proportions. Br. J. Nutr. 52:261-275. https://doi.org/10.1079/BJN19840094.

Williams, A. G., and G. S. Coleman. 1992. The Rumen Protozoa. Springer-Verlag, New York, NY.

Yang, C., J. A. Rooke, I. Cabeza, and R. J. Wallace. 2016. Nitrate and inhibition of ruminal methanogenesis: Microbial ecology, obstacles, and opportunities for lowering methane emissions from ruminant livestock. Front. Microbiol. 7:132. https://doi.org/10.3389/fmicb .2016.00132.

Ye, D., S. K. R. Karnati, B. Wagner, J. L. Firkins, M. L. Eastridge, and J. M. Aldrich. 2018. Essential oil and monensin affect ruminal fermentation and the protozoal population in continuous culture. J. Dairy Sci. 101:5069-5081. https://doi.org/10.3168/jds .2017-13646.

Yu, Z., and M. Morrison. 2004. Improved extraction of PCR-quality community DNA from digesta and fecal samples. Biotechniques 36:808-812. https://doi.org/10.2144/04365ST04.

Zhao, L., Q. Meng, L. Ren, W. Liu, X. Zhang, Y. Huo, and Z. Zhou. 2015. Effects of nitrate addition on rumen fermentation, bacterial biodiversity and abundance. Asian-Australas. J. Anim. Sci. 28:1433-1441. https://doi.org/10.5713/ajas.15.0091.

Zhou, Z., Z. Yu, and Q. X. Meng. 2012. Effects of nitrate on methane production, fermentation, and microbial populations in in vitro ruminal cultures. Bioresour. Technol. 103:173-179. https://doi.org/ 10.1016/j.biortech.2011.10.013.

\section{ORCIDS}

B. A. Wenner (1) https://orcid.org/0000-0002-2333-1297

B. K. Wagner ( ) https://orcid.org/0000-0002-8197-5437

N. R. St-Pierre @ https://orcid.org/0000-0002-9399-4061

Z. T. Yu (1) https://orcid.org/0000-0002-6165-8522

J. L. Firkins @ https://orcid.org/0000-0003-3518-1940 